\title{
Application of Porphyrins in Antibacterial Photodynamic Therapy
}

\author{
Bamidele M. Amos-Tautua ${ }^{1,2}$, Sandile P. Songca ${ }^{3}$ and Oluwatobi S. Oluwafemi ${ }^{1,2, *(1)}$ \\ 1 Department of Chemical Sciences (Formerly Applied Chemistry), University of Johannesburg, Doornfontein \\ Campus, P.O. Box 17011, Doornfontein 2028, South Africa \\ 2 Centre for Nanomaterials Science Research, University of Johannesburg, Johannesburg 2000, South Africa \\ 3 Department of Chemistry, University of KwaZulu-Natal, Private Bag X 54001, Durban 4000, South Africa \\ * Correspondence: oluwafemi.oluwatobi@gmail.com; Tel.: +27115599060
}

Academic Editor: Derek J. McPhee

Received: 4 June 2019; Accepted: 28 June 2019; Published: 4 July 2019

check for

\begin{abstract}
Antibiotics are commonly used to control, treat, or prevent bacterial infections, however bacterial resistance to all known classes of traditional antibiotics has greatly increased in the past years especially in hospitals rendering certain therapies ineffective. To limit this emerging public health problem, there is a need to develop non-incursive, non-toxic, and new antimicrobial techniques that act more effectively and quicker than the current antibiotics. One of these effective techniques is antibacterial photodynamic therapy (aPDT). This review focuses on the application of porphyrins in the photo-inactivation of bacteria. Mechanisms of bacterial resistance and some of the current 'greener' methods of synthesis of meso-phenyl porphyrins are discussed. In addition, significance and limitations of aPDT are also discussed. Furthermore, we also elaborate on the current clinical applications and the future perspectives and directions of this non-antibiotic therapeutic strategy in combating infectious diseases.
\end{abstract}

Keywords: antibacterial photodynamic therapy; porphyrins; bacteria; light; nanoparticles

\section{Introduction}

The rapidly growing resistance of bacteria to antibiotics has been regarded as one of the most important clinical challenges facing the entire world today. Antibiotics are traditionally used to control, treat, or prevent bacterial infections. However, in recent years, resistance is becoming more of a problem, especially in hospitals. Improper prescriptions of anti-effective agents in the environment and frequent transmission of microorganisms across the world by people travelling around the globe also constitute a major concern [1]. Several epidemiological reports have shown that bacterial resistance to all known classes of traditional antibiotics has greatly increased in the last 20 years, especially in hospitals rendering certain therapies ineffective [2]. For instance, it was reported that there was a significant increase of methicillin resistant Staphylococcus aureus type 002 isolates from hospitals in the United States in 2013 [3]. In addition, about 10\% of patients were appraised by the Centers for Disease Control and Prevention (CDC) who develop a hospital-acquired infection when admitted into hospitals in the United States of America; many of which die because of their infections [4]. The situation is more critical in the developing world where the infection rate is about $75 \%[5,6]$. The statistics for South Africa probably fall somewhere in between the foregoing percentage numbers [7].

However, the recent advances in the search for new antibiotics are not adequate to deal with the growing rate of resistant bacteria strains that have emerged in this century [2]. To limit this emerging public health problem there is a need to develop non-incursive, non-toxic, and new antimicrobial techniques that act more effectively and quicker than the current antibiotics [8-10]. One of these methods is antibacterial photodynamic therapy (aPDT) [11-13]. Several reports have revealed that 
aPDT is effective against traditional resistant strains in clinical trials [14-16], animal models [17,18], and in vitro [19-21]. For example, in vitro tests revealed that aPDT efficiently destroy a clinical isolate of Pseudomonas aeruginosa, which is considered as one of the life-threatening nosocomial pathogens [22].

\subsection{Antibacterial Photodynamic Therapy (aPDT)}

Photodynamic therapy is traditionally used against cancer in malignant and non-malignant tumors [23]. The suggestion to use PDT for microbial destruction came into reality in the mid-1990s as bacteria cells replicate at a very high rate, much like those of malignant cells [24]. Antibacterial photodynamic therapy, therefore, is a non-antibiotic process, which produces bacterial cell death in the presence of photosensitizing drugs, light energy of appropriate wavelength, and molecular oxygen $[25,26]$.

\subsubsection{Mechanism of Porphyrin Photosensitization: Photophysical and Photochemical Processes}

During aPDT, the photosensitizer (PS) is added to a bacterial sample, and the PS-bacteria mixture is irradiated with visible light of a wavelength, which causes excitation of the PS to its singlet excited state. The excited singlet state is unstable and lives for less than $1 \mu \mathrm{s}$. It can fall back to the ground state via emission of a secondary photon in the form of fluorescence (Figure 1). The singlet state undergoes intersystem crossing into the excited triplet-state to produce a therapeutic effect [24]. It plays the most significant role in the photochemical reactions involved in the lethal photosensitization (LP) process $[27,28]$. The PS triplet state can also phosphoresce by obtaining correct spin orientation of its excited electron. It can produce chemical changes in the bacterial cell via two competing pathways, named type I and type II reaction.

\subsubsection{Type I Reaction}

This is characterized by dependence on target substrate concentration. The triplet state PS can transfer its energy in the form of an electron or proton to a substrate within the cell (e.g., water in the cell membrane or the cytoplasm), to produce radical ions, which, in turn, react with oxygen to produce cytotoxic reactive oxygen species (ROS) such as superoxide $\left(\mathrm{O}^{2-}\right)$, hydrogen peroxide $\left(\mathrm{H}_{2} \mathrm{O}_{2}{ }^{-}\right)$, and/or hydroxyl radicals $\left(\mathrm{OH}^{-}\right)$. These highly reactive radicals can pass quickly through cell membranes causing oxidative damage and cannot be expelled from the cell. They can also react with organic substrates (e.g., fatty acid, lipids, oxygen) in a series of chain reactions to produce more cytotoxic radicals [29]. 


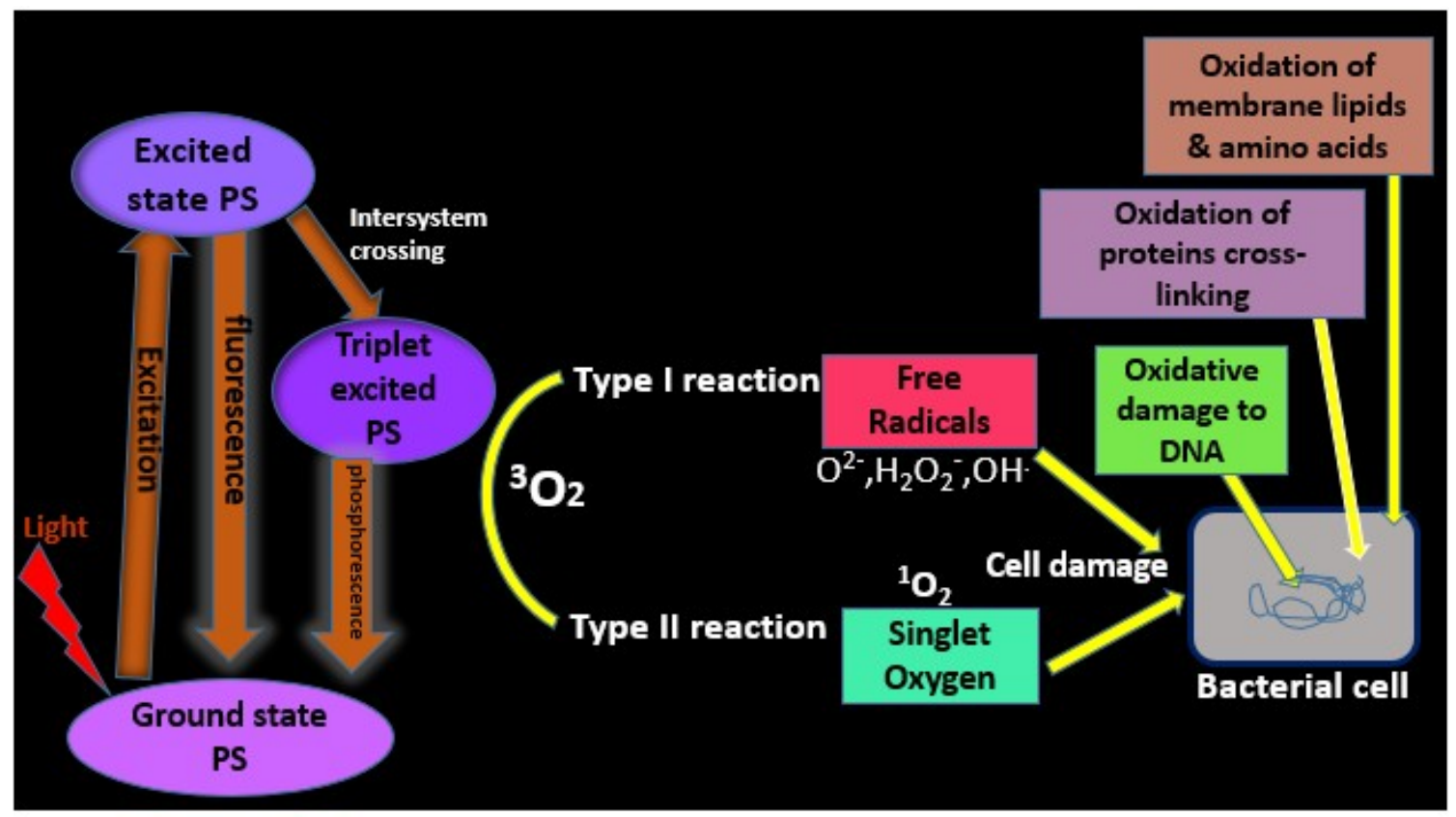

Figure 1. Schematic illustration of photodynamic reaction on bacterial cell [30].

\subsubsection{Type II Reaction}

This is characterized by dependence on oxygen concentration. The triplet state PS can transmit its energy directly to triplet ground state molecular oxygen $\left({ }^{3} \mathrm{O}_{2}\right)$ found in most cells to form excited state singlet oxygen ${ }^{1} \mathrm{O}_{2}$ [31]. PDT relies on the production of ${ }^{1} \mathrm{O}_{2}$ as the predominant cytotoxic ROS for its lethal effects. It reacts with more than one target within a cell including DNA bases, proteins, and cholesterol found in cell membranes [32].

These ROSs cause bacterial cell death through several mechanisms. These include oxidation of membrane lipids and amino acids in proteins, cross-linking of proteins, and oxidative damage to nucleic acids, which results in the disruption of the normal functioning of the microorganism (Figure 1). This is the principal route of bacterial cell death in vitro [33,34].

The singlet oxygen has been considered the main ROS through which the PS exert their photodynamic action [35-37] and it has also been shown to inactivate the antioxidant enzymes such as superoxide dismutase, catalase, and peroxidase [38,39].

Many of the PSs such as porphyrins, chlorins, and phthalocyanines utilized for aPDT studies have the macrocyclic tetrapyrrole nucleus, however, porphyrins are the most widely used PDT drugs.

\subsection{What Are Porphyrins?}

The word "porphyrin" is derived from the Greek word "Porphura" meaning "Purple". Porphyrins are a large group of fluorescent crystalline intensely colored pigments with natural or synthetic origin $[40,41]$. They are made up of a substituted aromatic macrocyclic ring consisting of four pyrrole-type residues, connected by four methine groups (Figure 2). 

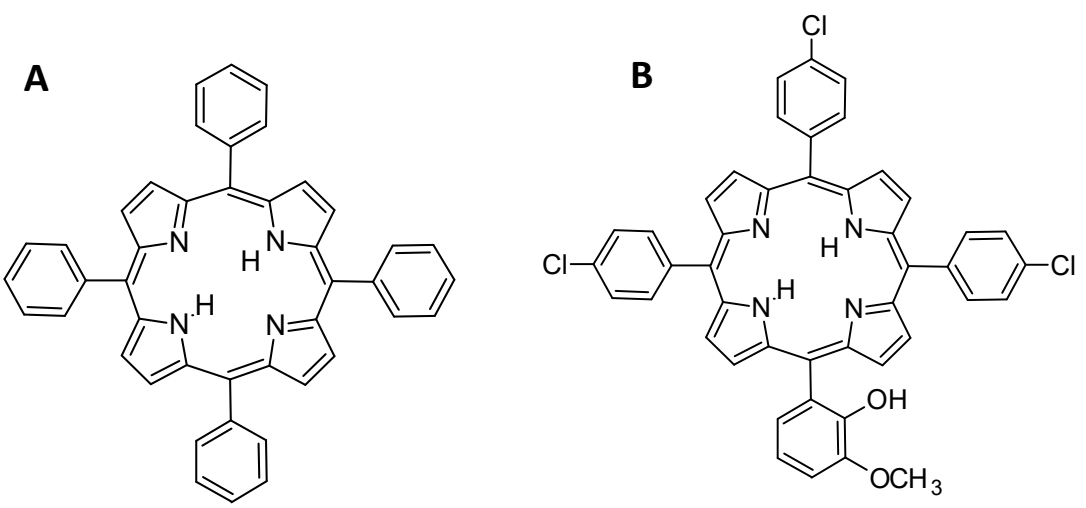

Figure 2. (A) Tetraphenylporphyrin and (B) 5,10,15-Tris(p-chlorophenyl)-20-(2-hydroxy-3-methoxyphenyl) $-21 H, 23 H$-porphyrin.

In compliance with Hückels rule of aromaticity ( $4 n+2 \pi$ electrons), the porphyrin nucleus possesses a total of $22 \pi$ electrons, with $18 \pi$ electrons delocalized over the macrocycle. Due to their aromatic nature, porphyrins generally participate in electrophilic substitution reactions at the meso positions, which are the most electron dense and, as such, are the most reactive [40]. Porphyrins have very intense absorption bands in the visible region due to the extensive electron delocalization within the macrocyclic molecules, which in turn, is responsible for their characteristic bright colors. They show a strong absorption band at $\sim 420 \mathrm{~nm}$, known as the Soret band and the weaker satellite absorption $Q$ bands between $600 \mathrm{~nm}$ and $800 \mathrm{~nm}$ (Figure 3) [42].

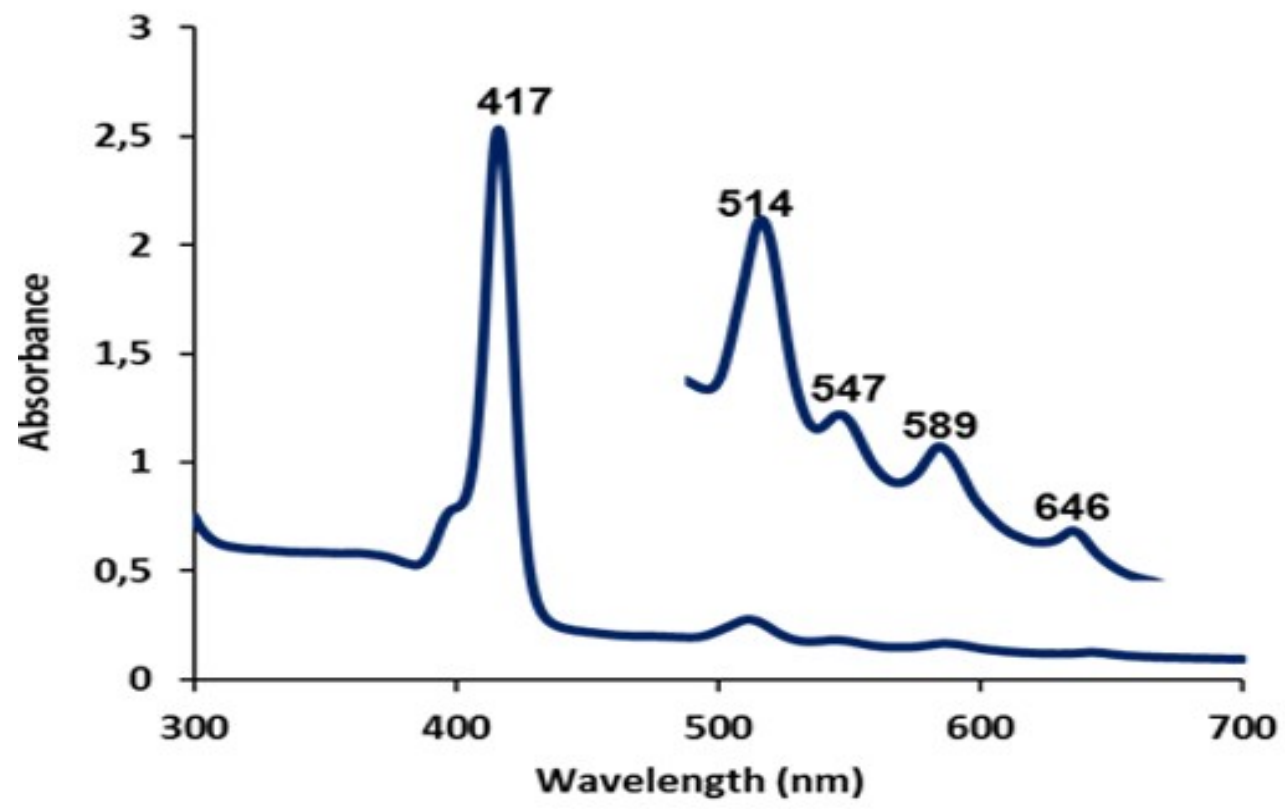

Figure 3. Absorption spectrum of meso-5,10,15,20-tetrakis(3,5-dimethoxyphenyl)porphyrin in dichloromethane.

\subsubsection{Porphyrins as Colors of Life}

Porphyrins are often regarded as colors of life because they are widely distributed in living tissues [40] where they participate in vital biochemical processes (Figure 4), namely the oxygen transport (myoglobin and hem) and the photosynthesis (chlorophylls). They are also involved in electron transport (cytochromes b and c), and $\mathrm{O}_{2}$ activation and utilization (cytochrome P450, cytochrome oxidase, and vitamin B12) [32]. 


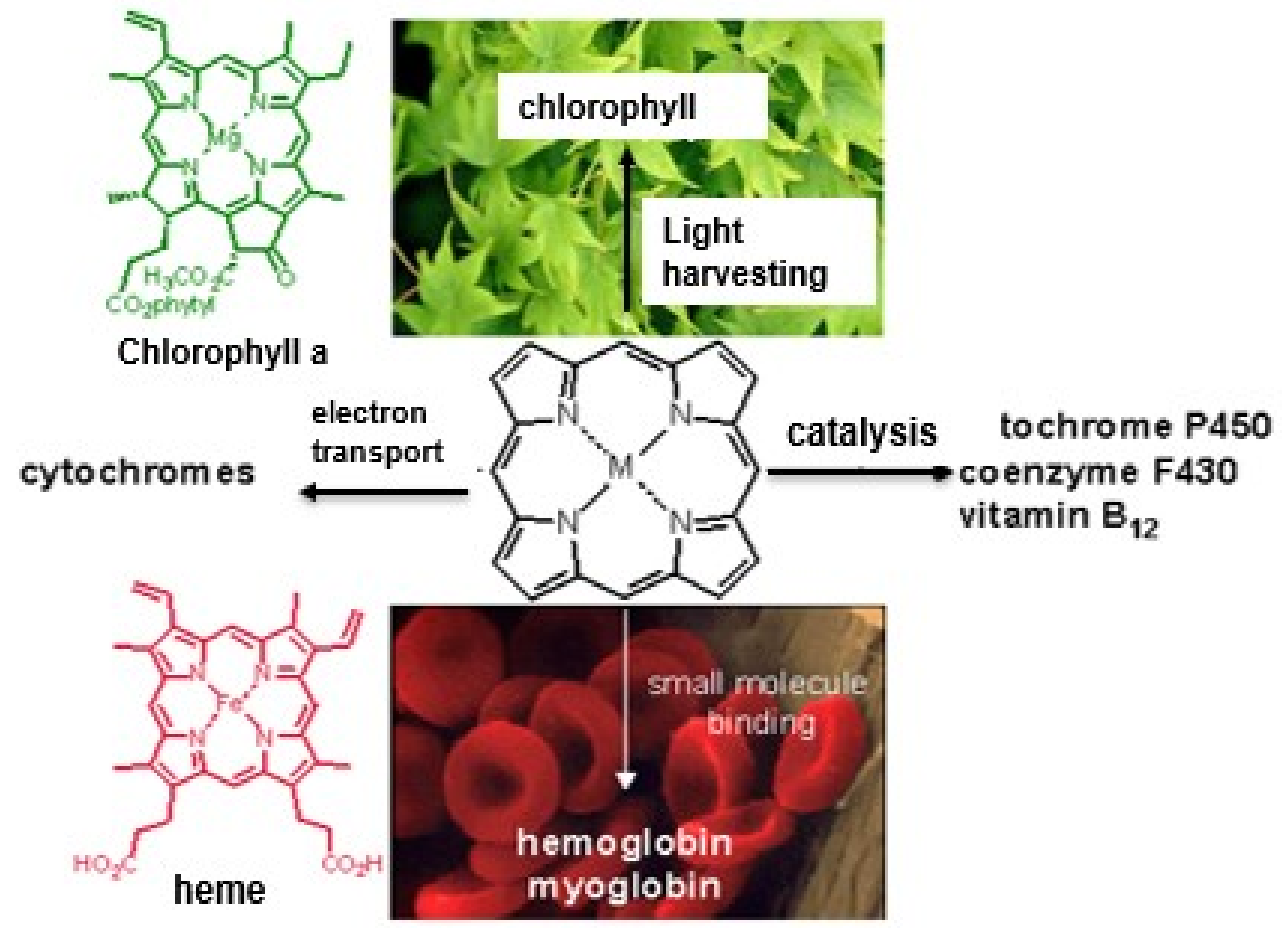

Figure 4. Porphyrins found in nature [43].

\subsubsection{Classification of Porphyrins}

Porphyrins can be classified as first and second generations [44]. The first-generation porphyrins are the primitive porphyrins known as hematoporphyrin derivatives $(\mathrm{HpD})$ present in the first commercially available PDT drug, Photofrin. These porphyrins are limited by impurity, poor in-depth light absorption, and photosensitivity [45]. The latter is an uncomfortable body reaction that occurs because of the activation of the photosensitizer remaining in the body by sunlight after PDT. The second-generation porphyrins, such as chlorin, bacteriochlorin, and phthalocyanine derivatives (Figure 5) emerged to resolve some of the problems associated with the first-generation porphyrins $[44,46]$. They are characterized with higher purity, better in-depth light absorption, and lesser photosensitivity [46].

A

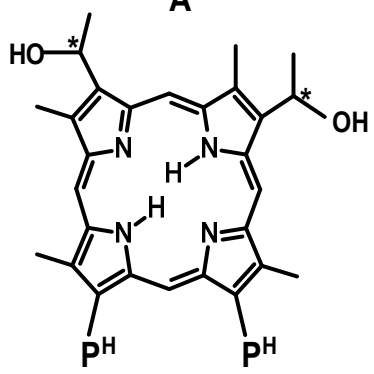

$\mathrm{PH}^{\mathrm{H}}=\mathrm{CH}_{3} \mathrm{CH}_{2} \mathrm{CO}_{2} \mathrm{H}$

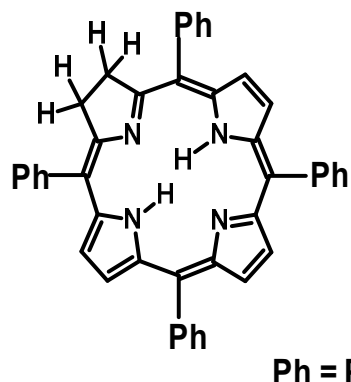

C

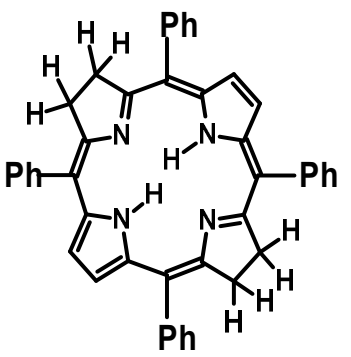

D

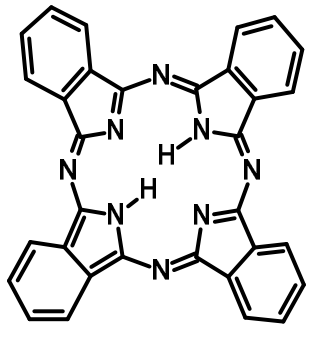

Figure 5. Structures of porphyrin derivatives. (A) Hematoporphrin (HpD); (B) Chlorin; (C) Bacteriochlorin; (D) Phthalocyanine [47].

\subsubsection{General Synthesis of Porphyrins}

The synthetic PSs studied in aPDT are based mainly on meso-tetra-arylporphyrins [48]. The popularity of this type of porphyrins results from their simple preparations and potentials toward 
further chemical transformations. In fact, the synthetic approaches usually involve the condensation of pyrrole with suitable aldehydes in one-flask or two-step one-flask procedures [49]. The wide range of available aldehydes provides porphyrins with different aryl or heteroaryl substituents at the meso-positions.

\section{Rothemund's Method}

Rothemund and Menotti [50] were the first to synthesize meso-tetraphenylporphyrin, thus pioneering the initial synthesis of meso-substituted porphyrins. The compound was obtained by reacting pyrrole and benzaldehyde in pyridine, in a sealed tube at $220^{\circ} \mathrm{C}$ for $24 \mathrm{~h}$, with a yield of about $10 \%$ (Scheme 1).

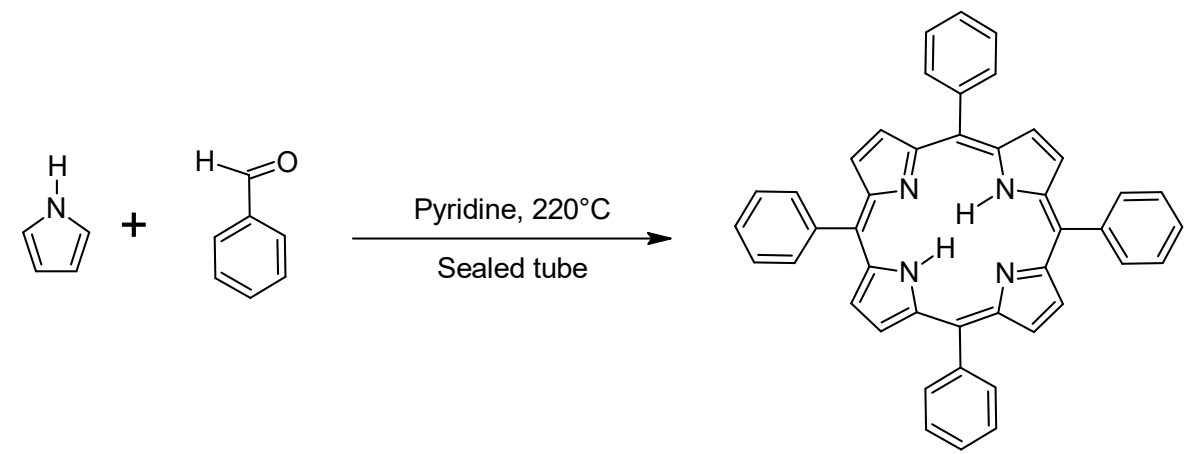

Scheme 1. Synthesis of tetraphenylporphyrin via Rothemund method.

Due to the relatively low yields and harsh reaction conditions, efforts were subsequently geared towards developing more efficient reaction conditions that would enable the preparation of a wider variety of meso-substituted porphyrins with higher yields.

\section{Adler-Longo's Method}

Adler and Longo [51] later modified the Rothemund and Menotti method under milder reaction conditions. The reaction modification involved refluxing pyrrole and benzaldehyde in propionic acid for 30 mins at $141^{\circ} \mathrm{C}$ (Scheme 2). This affords many more substituents on the benzaldehyde to be converted to their corresponding porphyrins in yields of up to $20 \%$. The disadvantage of this protocol is that purification of the product is tedious due to the production of a high degree of tar during the reaction. Also, attempts at making porphyrins from benzaldehydes bearing sensitive functional groups such as hydroxyl, thiol, and amino groups failed under these reaction conditions.

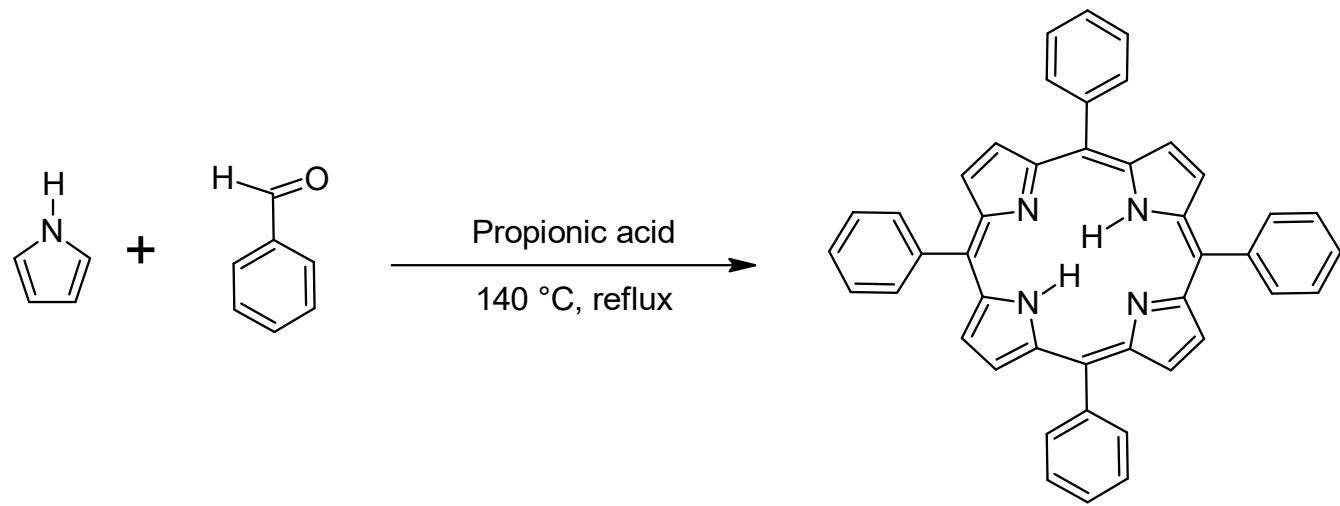

Scheme 2. Synthesis of Tetraphenylporphyrin via Adler-Longo's Method.

Regardless of these issues, the relative simplicity and robustness of Adler-Longo method is still regarded as the most effective in the large-scale preparation of porphyrins. 


\section{Lindsey's Method}

Lindsey and co-workers [49] developed a protocol that can be utilized to make porphyrins that require the use of acid-unstable aldehydes not generally used under Adler-Longo method. In the Lindsey reaction, equimolar concentrations of pyrrole and benzaldehyde are reacted with trifluoroacetic acid (TFA) or boron trifluoride etherate $\left(\mathrm{BF}_{3} . \mathrm{OEt}_{2}\right)$ as catalysts, at room temperature, under an inert gas atmosphere for $1 \mathrm{~h}$ in dichloromethane (DCM) as solvent, using a water scavenger (triethyl orthoacetate). This is followed by the addition of 2,3-dichloro-5,6-dicyanobenzoquinone (DDQ) to convert the prophyrinogen intermediate to porphyrin (Scheme 3). The advantages of this method are that it allows more facile purification and affords higher yields.

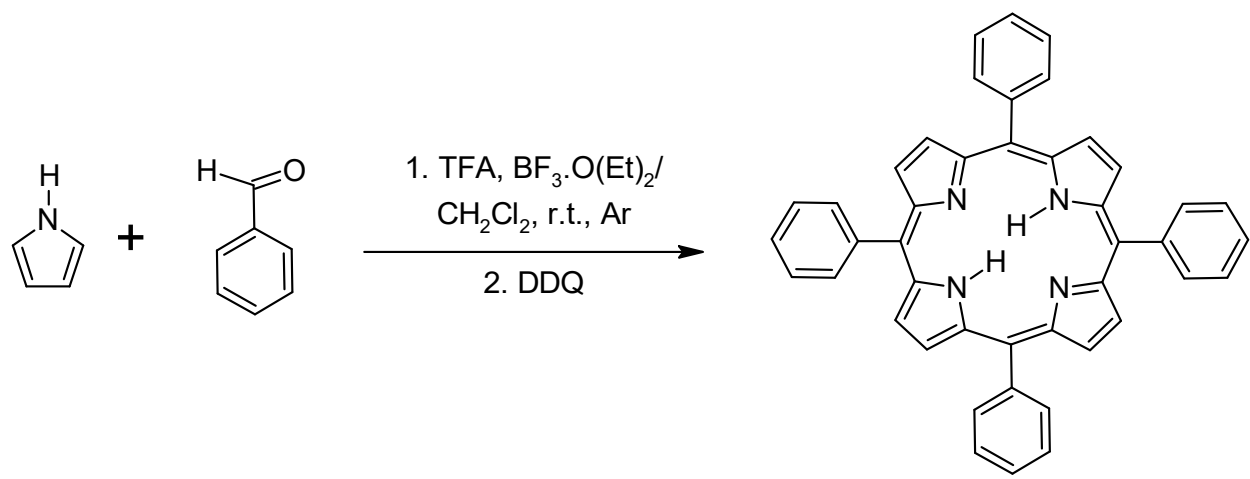

Scheme 3. Synthesis of meso-tetraphenylporphyrin via Lindsey's Method.

Other Synthetic Methods

There is a growing need for the development of new synthetic routes involving environmentally sustainable processes, hence, some strategies were recently adopted to prepare meso-substituted porphyrins using alternative energy sources, reaction media, and catalysts, including microwave irradiation, water as solvent, or solid acid catalysts. These synthetic methods are discussed in the following sections.

\section{Microwave-Assisted Synthesis}

Zerrouki et al. [52] employed microwave-activated two-step synthetic approach to prepare some unsymmetrical $\mathrm{A}_{3} \mathrm{~B}$ type meso-tetraarylporphyrins. Benzaldehyde, pyrrole, dichloromethane, and a $10 \%$ molar equivalent of molecular iodine were activated under microwave (MW) irradiation, then p-chloraniline was added and a second session of microwave irradiation was effected (Scheme 4).

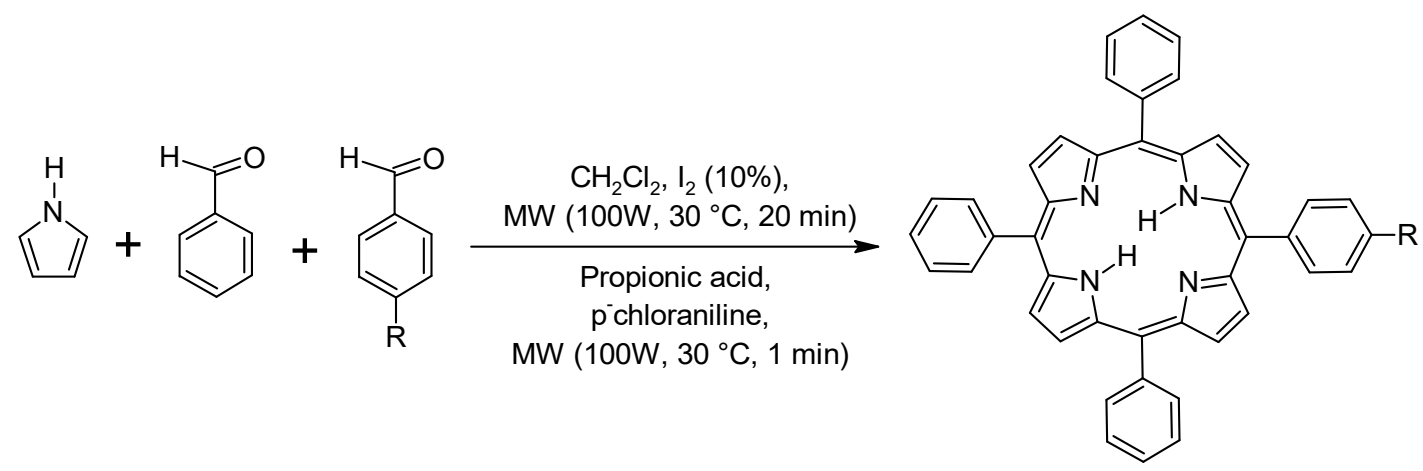

Scheme 4. Synthesis of meso-substituted porphyrins under microwave irradiation.

To avoid inconvenient conditions, such as the use of propionic acid, catalytic amount of iodine was used as an acid promoter. The advantages of this protocol over other methods are that it uses 
reagents and solvents without the need for prior distillation, it is very easy to perform, and gives the final meso-tetraphenylporphyrin product within a short reaction time with reasonable yields (47\%).

Water has been used as potential solvent for hydrophobic organic acid or as base catalyst and, in some cases, as oxidant because of its stability at temperatures above its boiling point and pressures above 16 bar [53]. These unique properties of overheated water under microwave irradiation have been employed for the preparation of meso-arylporphyrins. Henriques and co-workers [54] reported good to moderate yields of porphyrins under these reaction conditions (Scheme 5).

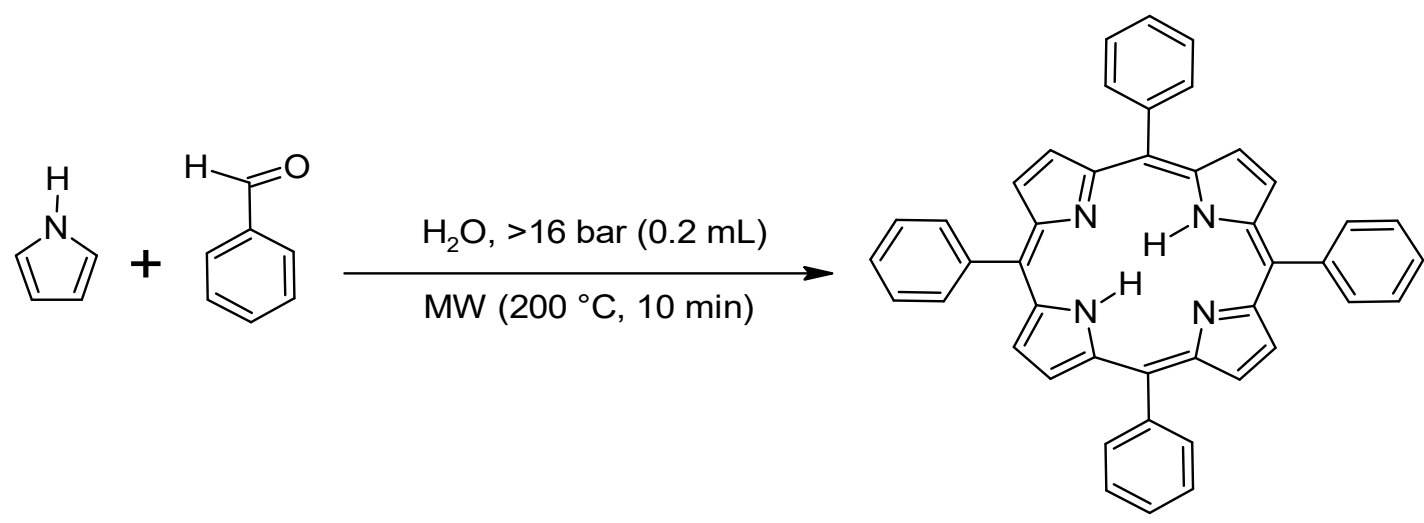

Scheme 5. Meso-substituted porphyrin obtained using water as solvent/oxidant microwave irradiation.

In another development, Joshi [55] described a 'greener' approach method for the synthesis of meso-arylporphyrins, in which the obnoxious strong organic acids (TFA, TsOH, and $\left.\mathrm{BF}_{3} \cdot \mathrm{Et}_{2} \mathrm{O}\right)$ are replaced by the acidic cation exchange resin Indion-130 (Scheme 6). The resin was used as a catalyst in the condensation of pyrrole with several substituted aromatic aldehydes, using triethyl-orthoacetate and dichloromethane as solvent.

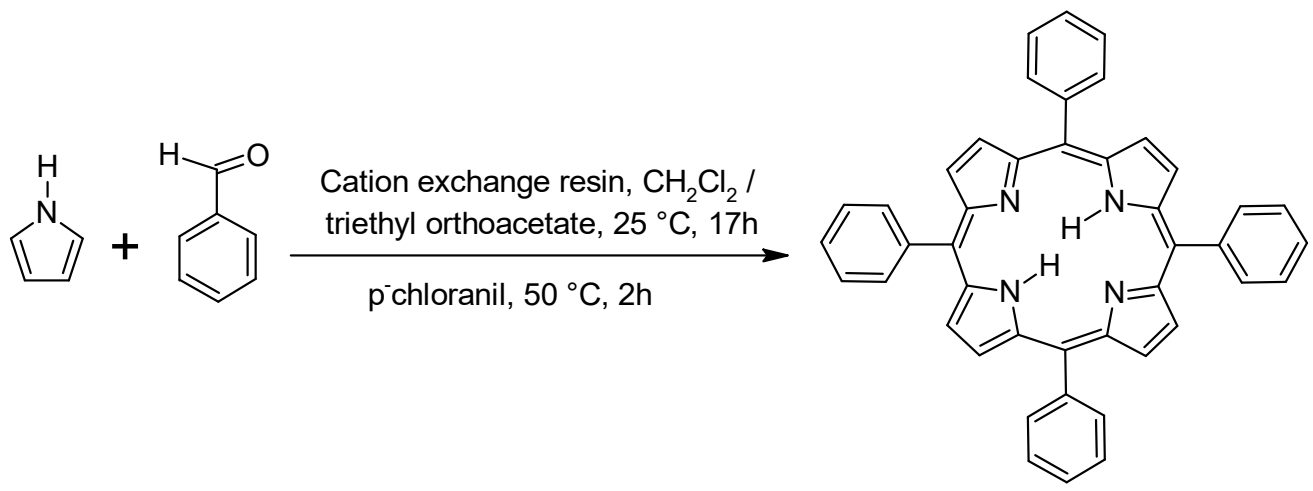

Scheme 6. Synthesis of meso-substituted porphyrins using solid acid catalysts.

Solventless Reactions

Drain and coworkers [56] developed a proficient one-step route for the synthesis of meso-tetraarylporphyrins using only oxygen as oxidant. Benzoic acid was added as adjuvant to the reaction mixture of pyrrole and benzaldehde (in gas phase) to improve the yield of the porphyrin (Scheme 7). 


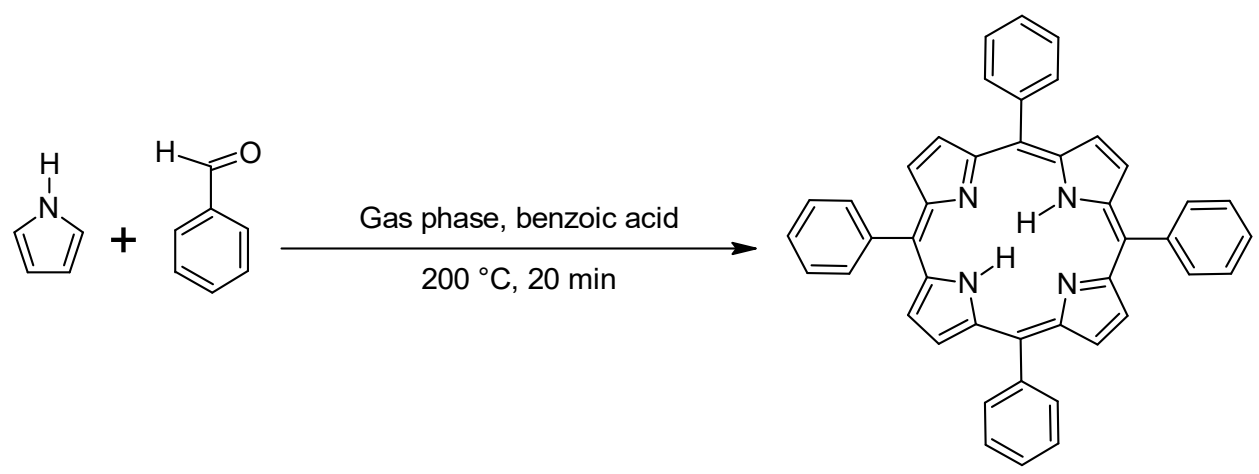

Scheme 7. Synthesis of meso-substituted porphyrins using solventless reaction conditions.

Ionic Liquids as Alternative Solvents

Chandramouli [57] reported a fast and efficient pathway for the synthesis of meso-tetra-arylporphyrins, using an acidic ionic liquid, 1-butyl-3-methylimidazolium tetrafluoroborate ([bmim $] \mathrm{BF}_{4}$ ) as solvent to catalyze the condensation of pyrrole with aryl aldehydes under Adler's reaction conditions (Scheme 8). The products were obtained in higher yields than those of the traditional Adler's method.

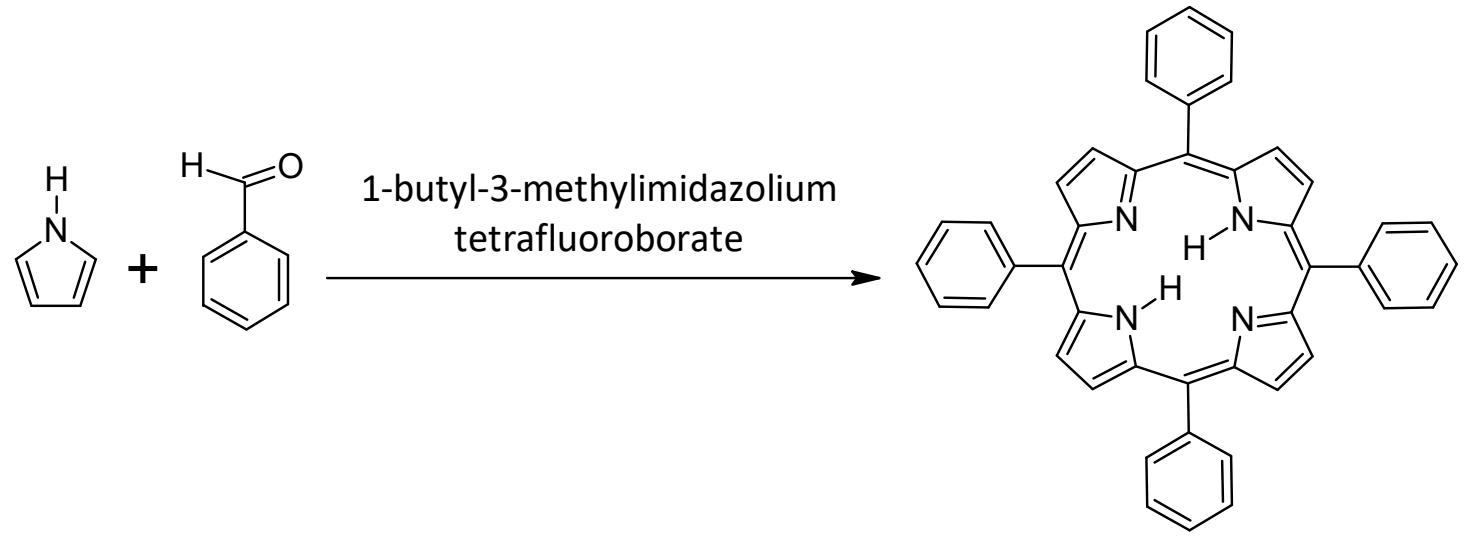

Scheme 8. Synthesis of meso-substituted porphyrins involving the use of ionic liquids.

\subsection{Unique Properties of Porphyrins as Drugs for aPDT}

Many groups have shown porphyrins to be efficient PSs for use in aPDT. Porphyrins have demonstrated significant broad spectrum of action against Gram-(+) and Gram-(-) bacteria at very low concentrations $(0.1-5 \mu \mathrm{M})$. Their antibacterial activity induced photodynamic therapy shows the following unique properties.

- Porphyrins have relatively low toxicity in vitro and in vivo and can be functionalized to be water soluble or water insoluble [58].

- They can be cleared in a reasonable time from the body and rapidly from the skin to avoid photosensitive reaction [32].

- Porphyrins can also possess competent amphiphilicity and ability for numerous chemical modifications [59].

- They have high quantum yield (above 0.70 ) for ${ }^{1} \mathrm{O}_{2}$ generation and high one-photon absorption coefficient $\left(\approx 500,000 \mathrm{M}^{-1} \mathrm{~cm}^{-1}\right)$ [60].

- Porphyrins possess a high binding affinity to cellular components, membranes, proteins, and DNA [61,62]. 
- Furthermore, they have a "therapeutic window" whereby they are active in killing bacterial cells, including multi-drug resistant bacteria (e.g., MRSA), whilst not damaging cultured human cells $[11,63]$.

- Porphyrins possess large number of different mechanisms in affecting microbial and viral pathogens. The possibility of bacteria acquiring resistance will be sufficiently reduced $[1,64]$.

\section{Bacteria}

Although some bacteria are vital for our everyday health and wellbeing others can also cause infection, hence, methods of eradicating virulent bacteria are needed. Bacteria are generally classified into two groups; namely Gram-(+) such as Staphylococcus aureus, Bacillus subtilis, and Enterococcus faecalis and Gram-(-) such as Escherichia coli, Pseudomonas aeruginosa, and Klebsiella pneumonia [65].

\subsection{Differences in Membrane Structure Between Gram-(+) and Gram-(-) Bacteria}

Differences in the cell wall ultra-structure of Gram-(+) and Gram-(-) bacteria (Figure 6) play a remarkable role in the sensitivity of bacteria to LP. Generally, all classes of PS molecules bind efficiently to Gram-(+) bacteria and inactivate them but Gram-(-) bacteria are known to be more resistant to treatment with PS [66,67].

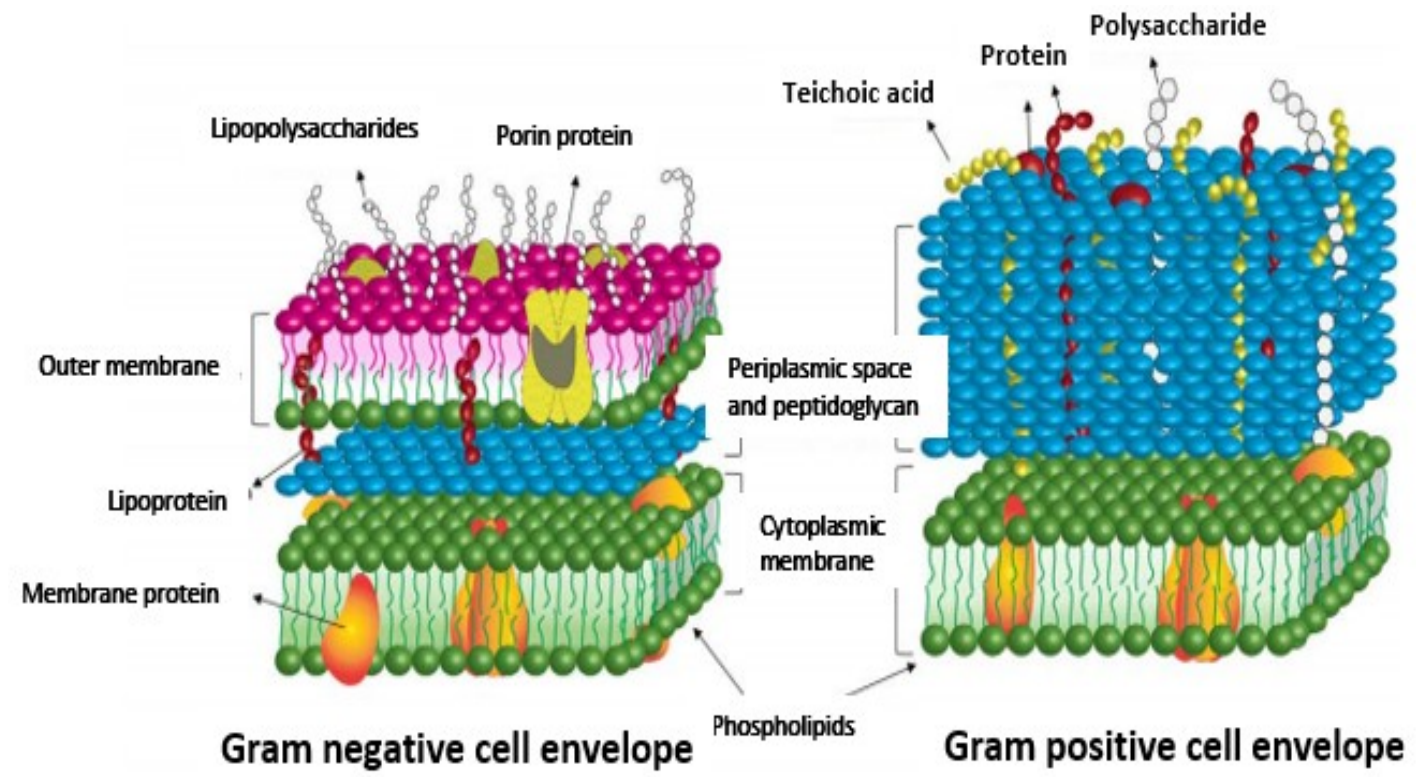

Figure 6. Schematic representation of cell wall and cytoplasmic membrane structure in Gram-(-) (left) and Gram-(+) (right) bacteria [12].

The high susceptibility of Gram-(+) species to PS is attributed to the presence of a relatively porous layer of peptidoglycan and lipoteichoic acid in their cell wall, which allows PS molecules to diffuse to the target sites within the cell. In contrast, the cell wall of Gram-(-) bacteria contains negatively charged lipopolysaccharide (LPS), which hinders the permeability of neutral or anionic porphyrins in the external environment into bacterial cell; however, cationic porphyrins interact effectively with these negatively charged surfaces of Gram-(-) bacterial cell wall and photo-inactivate them $[2,11,68]$.

There are two approaches to overcome this problem and achieve broad spectrum activity especially with neutral and anionic PSs. The first approach is to use membrane disorganizing agents to enhance their permeability such as polymyxin B nonapeptide (PMBN) or ethylenediaminetetraacetic acid (EDTA) [69]. These agents destabilize the cell wall structure by removing the $\mathrm{Mg}^{2+}$ and the $\mathrm{Ca}^{2+}$ ions, which neutralize the superficial negative charges. Malik and co-workers [70] found that pre-treating bacterial cells with EDTA results in the loss of a substantial amount of their LPS. Cells pre-treated 
with PMBN did not cause the release of LPS into the medium as with EDTA. The polycation displaces the divalent cations by binding strongly to the highly negatively charged surface. This causes an expansion on the surface of the outer membrane and allows the diffusion of hydrophobic molecules. Thus, the use of PMBN and EDTA widens the spectrum of photodynamic inactivation of bacteria.

The second approach is to attach a cationic polypeptide to the neutral or anionic PS molecule, so that it can bind to the negative charges of LPS [71,72].

Another solution is increasing the selectivity of the PS to the target micro-organism [73]. This can be accomplished through the conjugation of the PS molecule to monoclonal antibodies or bacteriophages, which allow selective binding to specific structures of the target microorganism. This approach can limit the destruction to host tissues surrounding the infected area. These techniques have been verified successfully in vitro against MRSA $[48,74,75]$ and in vivo against a P. aeruginosa skin-infection model in mice $[20,76,77]$.

\subsubsection{Mode of Porphyrin Action on Bacterial Cell}

Larson and Marley [78] have described three modes of action by which light-activated antimicrobial agents can interact with the cell:

1. The first is that the PS settles outside the cell, generating reactive oxygen species in solution, which can diffuse into the cells of the target organism and react to induce cellular damage.

2. The second mechanism is that the PS binds to or becomes localized at the cell membrane (by hydrophobic or coulombic interactions) - upon light absorption, the PS transfers energy (e.g., an electron, hydrogen atom etc.) to target biomolecules within the cell, resulting in ROS production that cause cell damage. Anionic porhphyrins follow this mechanism of photosensitization.

3. The third possibility is that the PS penetrates the interior of the cell and becomes associated with an intracellular target, possibly a protein (inducing enzymatic damage) or the nucleus (inducing genetic damage). Cationic porphyrins that bind strongly to the polyanionic macromolecules such as DNA are good examples of this type of phototoxic agent [79].

\subsubsection{Mechanisms of Porphyrin Photodynamic Inactivation of Bacteria}

The mechanisms by which porphyrins cause bacterial cell death are complex and non-specific. Many investigators [37,68,80-82] have suggested that the ROS generated from type I and II reactions can cause microbial cell damage via three main mechanisms.

Functional Damage

These comprise the inactivation of essential enzymes, oxidation of protein-protein cross-links, and inhibition of metabolic processes such as DNA synthesis, and glucose transport $[11,34]$.

\section{Morphological Changes}

These include alteration of mesosome structure [83]. Mesosomes are invaginations of the plasma membrane responsible for the synthesis of cross-wall in dividing bacteria. They are usually tubular, vesicular, or lamellae in shape [84]. When porphyrins bind to the plasma membrane of bacteria, the structure of mesosomes are altered and they take a laminated, myelin-like form, which subsequently disrupt the division of bacterial cells.

Cell Membrane Damage

This may result in the breaking down of cellular contents and subsequent disruption of the membrane transport system and enzymes $[85,86]$.

Although some damages to the nucleic acid may occur, it has been discovered that these damages can be repaired by DNA repairing systems $[87,88]$. 


\section{Choice of Light Source}

The choice of light source to photo-inactivate pathogens depends primarily on the depth of the infected tissues into which the light should penetrate. The selected wavelength must match the absorption spectrum of the PS of choice. The most effective irradiation is that in the red and NIR range of the spectrum [89].

A few collections of light sources (Figure 7) have been used over the years. The most popular laser being the Argon dye laser, with tuneable wavelength that is suitable to that of the optimum absorption wavelength of the PS. However, they are costly, need an external water-cooling system and separate power supply, as well as a lot of maintenance [90].

The He-Ne laser and the semiconductor diode lasers are two laser systems that have been used widely for photodynamic inactivation of bacteria in recent years. They are cost effective because of their small size, handiness, dependability, and reasonably cheapness. However, the wavelength generated is not tuneable, hence, has to be pre-matched for a chosen PS [91]. The He-Ne laser radiates at 632.8 $\mathrm{nm}$ while other semiconductor diode lasers emit at longer wavelength of 630-950 nm.

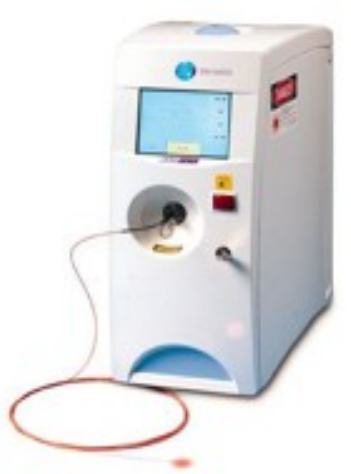

$732 \mathrm{~nm}$ Laser

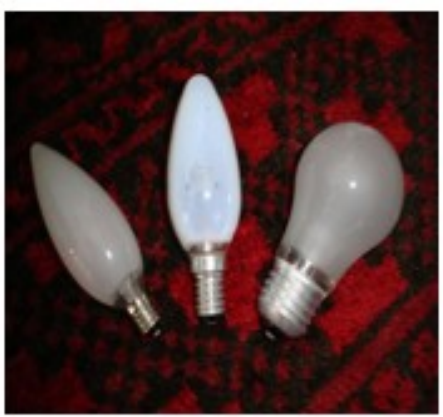

Incandescent light bulbs

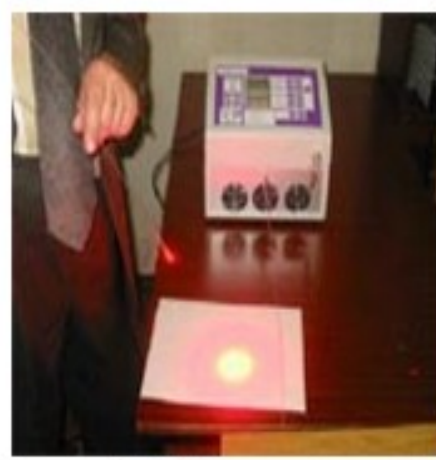

"Crystal 2000" semiconductor laser device.

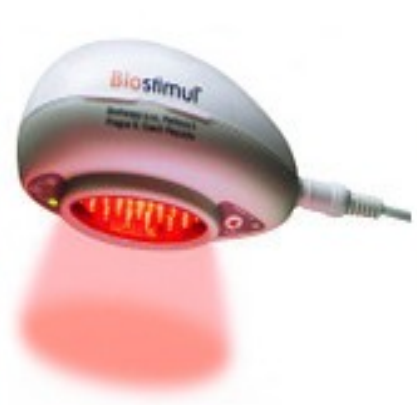

BioStimul Lamp

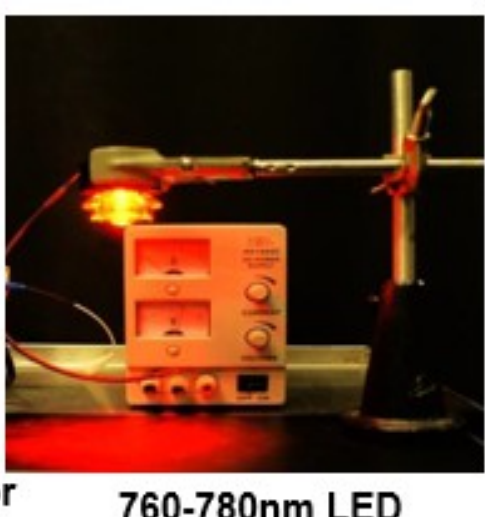

760-780nm LED

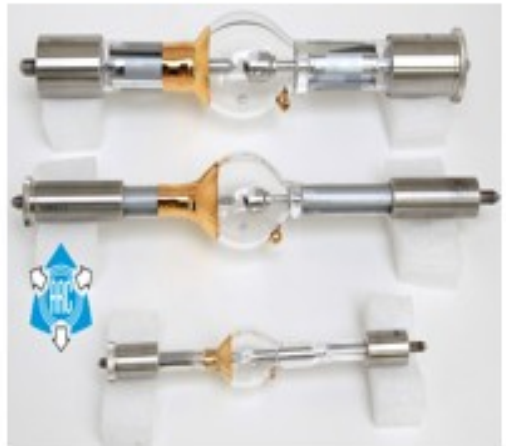

Mercury-Xenon arc lamp

Figure 7. Examples of light sources [92].

Non-laser light sources are used primarily in dermatology. These sources are regular lamps that produce incoherent light, generate a lot of heat, whose output wavelength is achieved by using filters [93]. There are many varieties of lamps that emit incoherent light with continuous spectrum such as incandescent lamps, xenon arc lamps, and those with the spectrum in bands (gas discharge lamps or metallic vapor lamps), which have been used to lethally photo-inactivate some of the pathogens associated with wound infections [91].

For example, a halogen lamp with a wavelength range between $350-800 \mathrm{~nm}$ at an intensity rate of $90 \mathrm{~mW} / \mathrm{cm}^{2}$ in combination with porphyrin has been used successfully to inactivate E. coli [94]. 
However, for in vitro aPDT studies, broadband light sources such as broad arrays of light-emitting diodes (LED) are considered suitable light sources [95]. LED are preferable than other light sources because of their large output, lower thermal tissue destruction, facile fabrication, large area illumination, and cost efficiency [96].

\section{Antibacterial Photodynamic Effects of Porphyrins}

Many groups have shown porphyrins to be efficient PSs for use in aPDT. Studies by Orenstein et al. [97] showed that it was possible to kill Staphylococcus aureus, a Gram-(+) bacterium, using deuteroporphyrin but Gram-(-) bacteria such as Escherichia coli and Pseudomonas aeruginosa could not be inhibited using deuteroporphyrin alone. Malik et al. [70] overcame this problem by pre-treating the cells with either EDTA or PMBN.

Other studies, conducted using meso substituted porphyrins, have also demonstrated that the molecules need to be cationic in order to photoinactivate both Gram- $(+)$ and Gram- $(-)$ bacteria. For example, Ragas and co-workers [82] investigated the potential of aryl cationic porphycenes as photosensitizing drugs in aPDT in vitro and in vivo infection models and noticed that the structural porphyrin isomer successfully inactivated different Gram-(+) and Gram-(-) bacterial and fungal cells. Zoltan et al. [98] also observed an efficient inactivation of Escherichia coli when meso-tetra(pyren-1-yl)porphyrin complexes of $\mathrm{Ni}(\mathrm{II}), \mathrm{Cu}(\mathrm{II})$, and $\mathrm{Zn}$ were tested against the bacteria.

Tavares et al. [99] examined the mechanisms of photodynamic inactivation (PDI) of bacteria using cationic porphyrins. They proposed that singlet oxygen is more responsible for the PDI process of the bioluminescent $E$. coli than free radicals generated by the cationic porphyrins.

Maisch et al. [100] studied the inactivation mechanism of several cationic porphyrins against different $S$. aureus and $E$. coli strains and concluded that the killing was mediated predominantly by ROS, including singlet oxygen. Furthermore, a novel porphyrin-based photosensitizer, XF73, has been reported by Taub et al. [101] to show high efficacy in killing MRSA without damage to healthy human cells. They concluded that this PS can inhibit MRSA infection in hospitals as well as for burns and other open wounds.

Nitzan and Ashkenazi [102] revealed the effects of illumination by different light sources at different wavelengths in Dinococcus radiodurans, using two different porphyrin derivatives; the hydrophilic cationic 5,10,15,20-tetrakis(N-methylpyridinium-4-yl)porphyrin (TMPyP) and the neutral derivative deuteroporphyrin (Dp). The most potent photo-destruction were obtained for both photosensitizers when $D$. radiodurans cultures were treated with blue light (400-450 nm). Blue, green, and red light were also used to induce photoinactivation of multiple antibiotic-resistant bacteria Acinetobacter baumannii and Escherichia coli by the cationic photosensitizer and similar results were obtained. Complete extermination of both bacteria was obtained with blue light [103].

Several studies have been conducted using (5,10,15,20-tetrakis( $N$-methylpyridinium-4-yl)porphyrin. For instance, Maisch et al. [104] found that cells of Vibrio fischeri and of Escherichia coli, and T4-like phages, that were photoinactivated in vitro to the detection limit in the presence of 5,10,15,20-tetrakis(N-methylpyridinium-4-yl)-20-(pentafluorophenyl)porphyrin triiodide do not recover their viability in laboratory conditions after one week.

Hanakova et al. [105] examined the antibacterial PDT effect of TMPyP $(5,10,15,20$-tetrakis (N-methylpyridinium-4-yl)porphyrin and ZnTPPS 4 (Zinc-5,10,15,20-tetrakis(4-sulphonatophenyl) porphyrin (Figure 8 ) bound to hp- $\beta$-cyclodextrin. They found that both porphyrins were able to reduce the growth of $S$. aureus and E. coli strains 


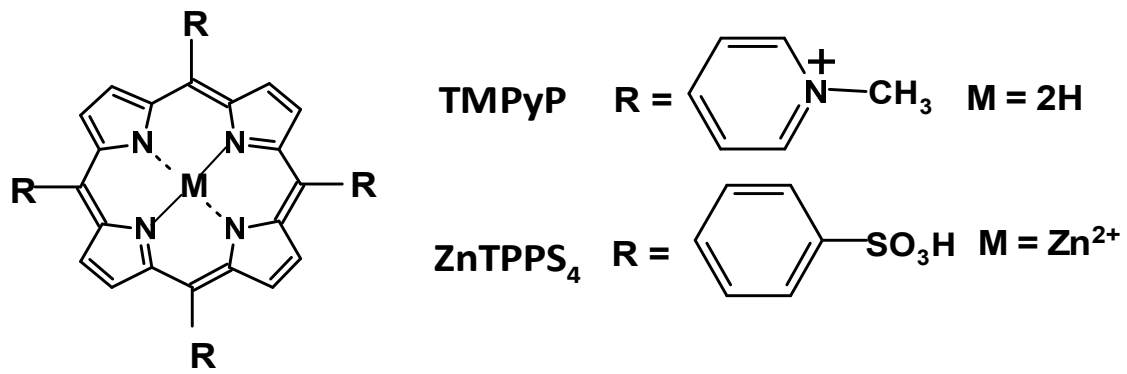

Figure 8. Structures of TMPyP and $\mathrm{ZnTPPS}_{4}$.

In a recent development, Ruiz-Gonzalez and co-workers [106] used the novel tricationic porphycene,2,7,12-tris(trimethyl- $p$-tolyl)-17-( $p$-(methoxymethyl)phenyl)porphycene $\left(\mathrm{NMe}_{3} \mathrm{MeO}-\mathrm{TBPo},\right)$ and its predecessor, 2,7,12-tris $(\alpha$-pyridinio- $p$-tolyl)-17-( $p$-(methoxymethyl)phenyl) porphycene ( $\mathrm{Py}_{3} \mathrm{MeO}-\mathrm{TBPo}$,) to photoinactivate Gram-(+) S. aureus and Gram-(-) species such as $P$. aeruginosa and E. coli.

Neutral porphyrins like 5,10,15,20-tetrakis(4-hydroxyphenyl)-porphyrin (THPP) have been considered as less phototoxic towards Gram-(-) bacteria. However, Wikene et al. [107] had shown that only nanomolar amounts of THPP (Figure 9) in natural deep eutectic solvents (NADES) were needed for complete photoinactivation of Enterococcus faecalis and Escherichia coli.
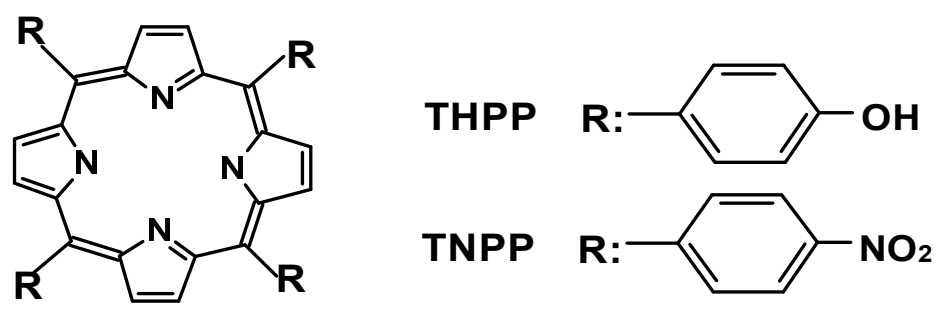

Figure 9. Structures of neutral porphyrins.

Rahimi et al. [108] also investigated the effect of 5,10,15,20-tetrakis(4-nitrophenyl)porphyrin (TNPP) and its zinc derivative on photoinactivation of P.aeruginosa and B. subtilis. The results show that photoactivated TNPP (Figure 9) and ZnTNPP have effective inhibitory activity against B. subtilis and $P$. aeruginosa, as compared with ampicillin. The interesting thing about TNPP and ZnTNPP antibacterial activity is that it seems to be more active against the Gram-(-) $P$. aeruginosa, than the Gram-(+) B. subtilis.

\section{Significance of aPDT}

Antibacterial effectiveness of PDT is considered a promising alternative to other kinds of antibiotic treatment for several reasons, which include its multi-target process, broad spectrum of action, broader therapeutic window than other antimicrobial therapies, even against pathogenic biofilms. Because of the high reactivity of ROS, secreted virulence factors can be destroyed as these are commonly proteins, enzymes, or amino acid residues [63]. aPDT is independent towards the resistance pattern of bacteria to antibiotics; it produces extensive bacteria reduction with restricted damage to healthy host tissue, and specifically delivers PS to the infected area $[81,83]$. It demonstrates fast inactivation than usual antimicrobials $[11,99,109,110]$. It shows absence of photo-resistant strains and viability recovery after multiple treatments [80,111-113]. It requires low infrastructure and equipment [114]. It is a simple-to-use and cost-effective therapeutic option for developing countries [115]. 


\section{Clinical Applications of aPDT}

Many clinical trials of porphyrins and aPDT have been carried out for the treatment of dermatological conditions [116-118]. Moreover, their intensive use in periodontitis [15,16,119,120] has opened a wider application in the treatment of other infectious diseases of microbial origin. It is currently envisaged that porphyrins would have application for treatment of topical human infections and to replace 'skin applied' antibiotics [121,122].

\subsection{Treatment of Wound Infections}

A wound is a breach of the skin that can lead to infection and sepsis. When the bacterial load exceeds $10^{5}$ organisms per gram of tissue, or when the immune system becomes suppressed, infection develops [123]. Hamblin and co-workers [11], using an animal model, demonstrated that bacteria infecting a wound could be destroyed photo chemically without affecting the healthy host cells. (Figure 10). E. coli present in the wound were quickly annihilated when chlorin(e6) photosensitizer conjugated with poly-L-lysine, was topically applied. Likewise, porphyrins showed to be very effective in destroying of $S$. aureus and selected viral pathogens in burn wound infections $[17,124,125]$. Barra et al. [126] explored the possibility of fighting biofilms produced by the Gram-(+) bacteria Staphylococcus species that commonly crowd superficial wounds and sores by combining PDT using 5 -aminolevulinic acid with an antibiotic, gentamicin. It was observed that the combined treatment effectively caused detachment of the biofilm and bacterial death. Research findings have shown that PDT has the capacity to destroy secreted virulence factors such as protease, which was speculated to be responsible for healing in P. aeruginosa-infected wounds [76,77].

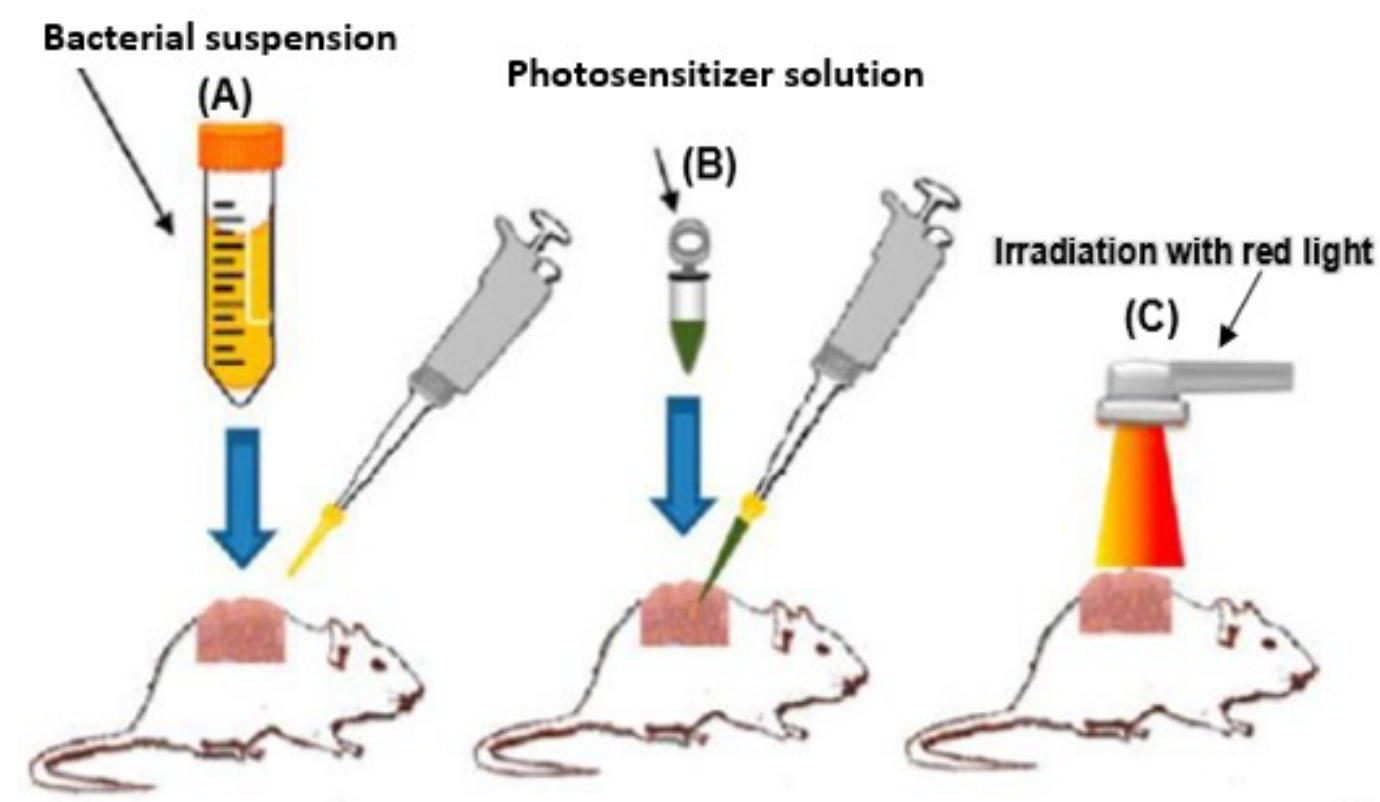

Figure 10. Schematic diagram showing the stages involved in carrying out antimicrobial PDT on a burn infection in mice. (A) Inoculation of the mouse with bacterial suspension; (B) injection with photosensitizer solution; $(\mathbf{C})$ irradiation of the infected site with red light $[11,77]$.

Recently, Bartolomeu [127] and her co-workers assessed the impact of photodynamic therapy (PDT) on the virulence factors of six strains of $S$. aureus using the photosensitizer (5,10,15,20-tetrakis( $N$-methylpyridinium-4-yl)porphyrin tetraiodide. They found out that the expression of some external virulence factors was affected by antimicrobial photodynamic inactivation (PDI) and enterotoxin producing strains were more susceptible to PDI than non-toxigenic strains. The result was that the surviving bacteria did not develop resistance to PDI treatment. 


\subsection{Treatment of Acne}

Acne is the most prevalent skin disease. It is a condition that occurs when hair follicles become clogged with oil (sebum) and dead skin cells. The commensal bacterium Propionibacterium acnes accumulate in these sebaceous follicles where they secrete enzymes that break down sebum and cause inflammatory acne lesions [128,129].

Meffert et al. [130] first reported the successful treatment of acne with visible light. Improvement on this therapy was achieved when the endogenous porphyrins of P. acnes was photo-inactivated with blue light (Figure 11) [131,132]. It was conceived that porphyrins through the generation of the cytotoxic singlet oxygen might boost the perifollicular inflammatory reaction and activate the expression of keratinocyte-derived IL-8 [133,134].
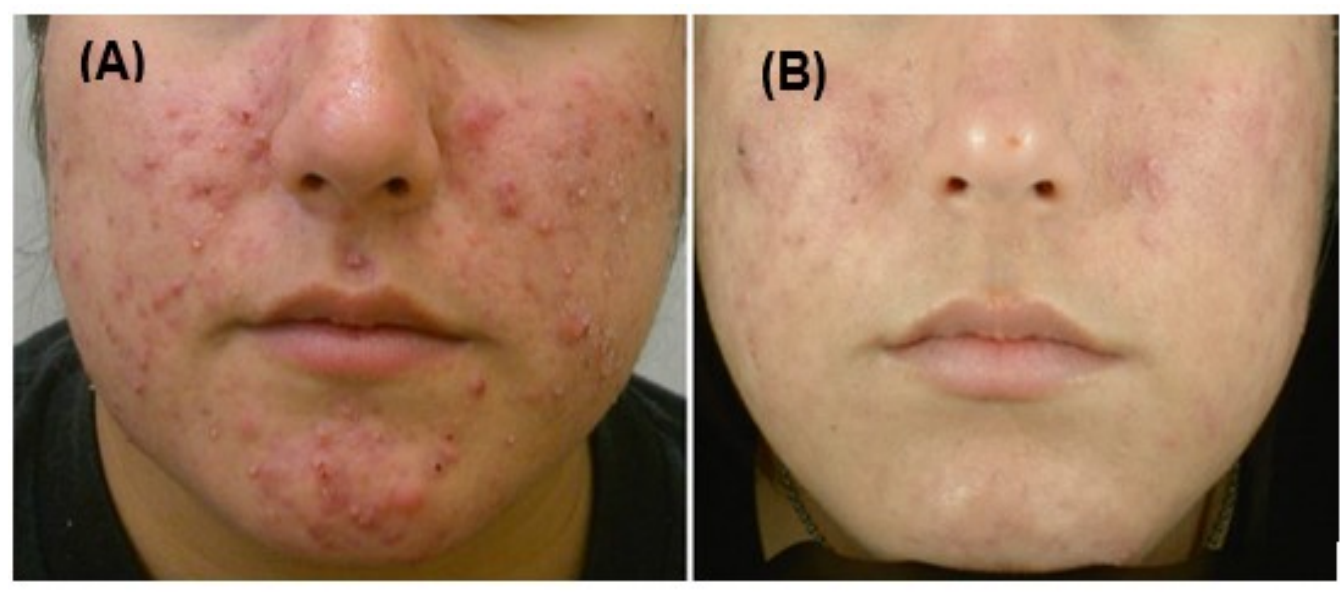

Figure 11. Acne treatment with blue light and endogenous, 5-aminolevulinic acid (ALA)-induced porphyrin. Before treatment (A); after six months of therapy (B) [89].

\subsection{Periondontal Diseases}

Dental infections are the greatest expanding field of clinical antibacterial PDT. Periodontal disease is caused by a set of pathogenic bacterial species that form plaques and accounts for periodontal inflammation and destruction. In vitro studies have revealed that many pathogens such as P. gingivalis, Fusobacterium nucleatum, and Staphylococcus sp, which are prevalent in the subgingival periodontal plaques, have been effectively exterminated by photodynamic treatment, both in aqueous suspension and as a biofilm [135]. In addition, Garcia et al. [136] observed that photodynamic therapy causes the reduction of periodontal tissue damage when compared to other treatment methods, such as scaling and root planning and antibiotic therapy.

The process of aPDT treatment of periodontal disease may involve injecting a porphyrin into the periodontal pocket, followed by irradiation with fiber optics inserted into the infected area (Figure 12). This method ensures that only the disease lesions are treated while other beneficial microflora remain unaffected. Likewise, Streptococci such as Fusobacterium nucleatum and Actinomyces viscosus, which causes dental caries, could also be attacked [11]. 

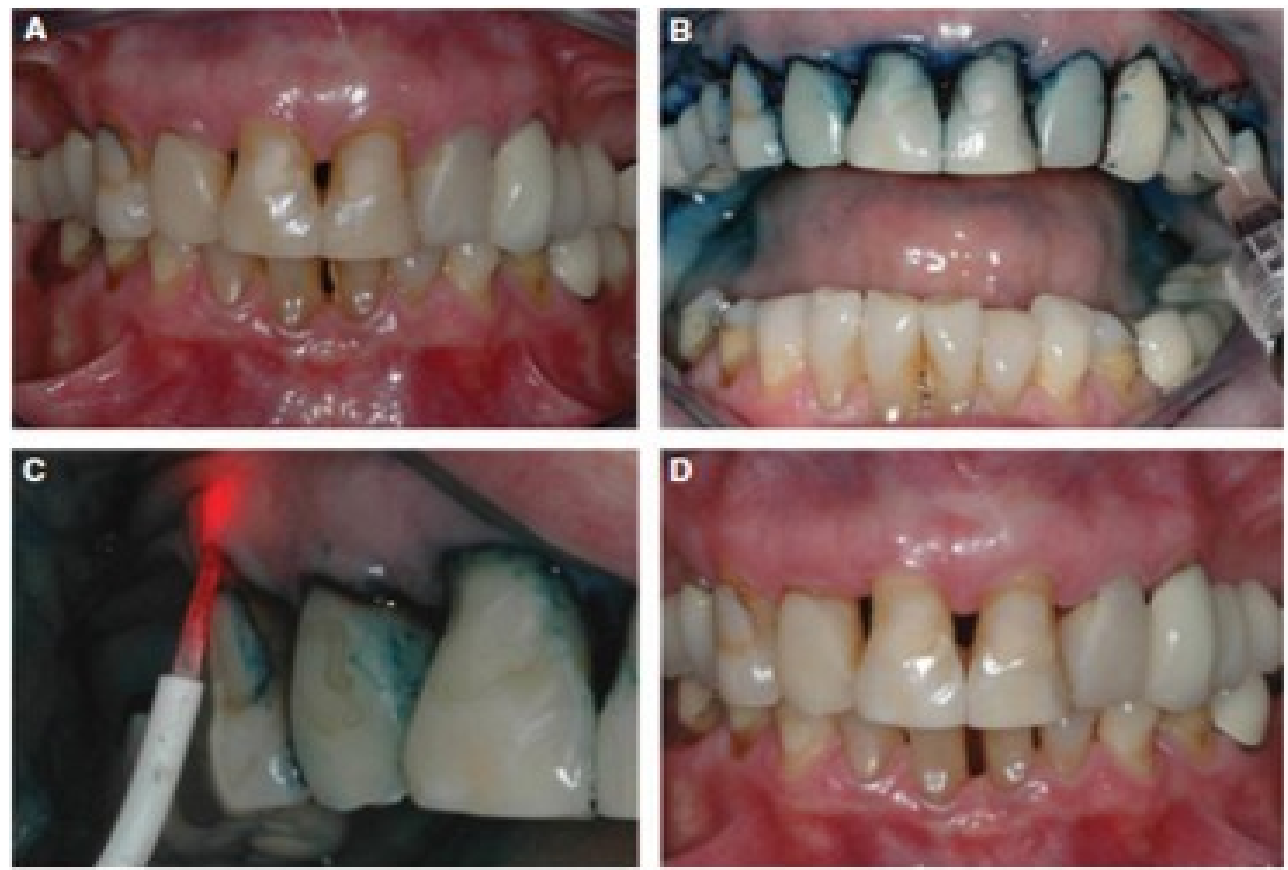

Figure 12. (A) Clinical situation of a patient before antibacterial photodynamic therapy (aPDT). (B) Injection of the photosensitizer. (C) Irradiation with the diode laser. (D) The clinical situation six months after therapy [137].

In a recent development, Cieplik et al. [138] evaluated the ability of (5,10,15,20-tetrakis ( $N$-methylpyridinium-4-yl)porphyrin tetra-( $p$-toluenesulfonate) and Methylene Blue to inactivate root canal bacteria, Enterococcus faecalis. They observed that photoinactivation of bacteria (PIB) with both PS led to reduction by $\leq 5 \log 10$ of E. faecalis CFU for each setup. Conclusively, they suggested that light activation of given intra-canal PS from outside a tooth may be possible at wavelengths $\leq 430$ $\mathrm{nm}$, facilitating clinical application of PIB in endodontics.

\subsection{Treatment of Environmental Waters}

Several studies have shown that aPDT is effective in the selective inactivation of pathogens in waste waters, hence it is being considered as an alternative for the treatment of environmental waters such as surface, ground, drinking, and waste waters [139-141]. This is demonstrated by the fact that Alves and colleagues [142] compared the efficiency of seven cationic porphyrins differing in meso-substituent groups, charge number, and charge distribution, (Figure 13) on the photodynamic inactivation of a Gram-(+) bacterium (Enterococcus faecalis) and a Gram-(-) bacterium (Escherichia coli). Some of the selected porphyrins have been shown to be efficient PS against other microorganisms such as sewage bacteriophage [143], bacterial endospores [144], sewage fecal coliforms [141], and recombinant bioluminescent $E$. coli [145]. Their results revealed that the various changes in the structures of the porphyrins had different effects on the photoinactivation of both bacteria. They concluded that the most active Tri-Py ${ }^{+}-\mathrm{Me}_{-} \mathrm{PF}_{4}$ porphyrin could serve as efficient photosensitizer that can efficiently destroy a large spectrum of environmental bacteria. This photodynamic approach shows that the application of porphyrins irradiated with natural light sources is cost effective and feasible. 

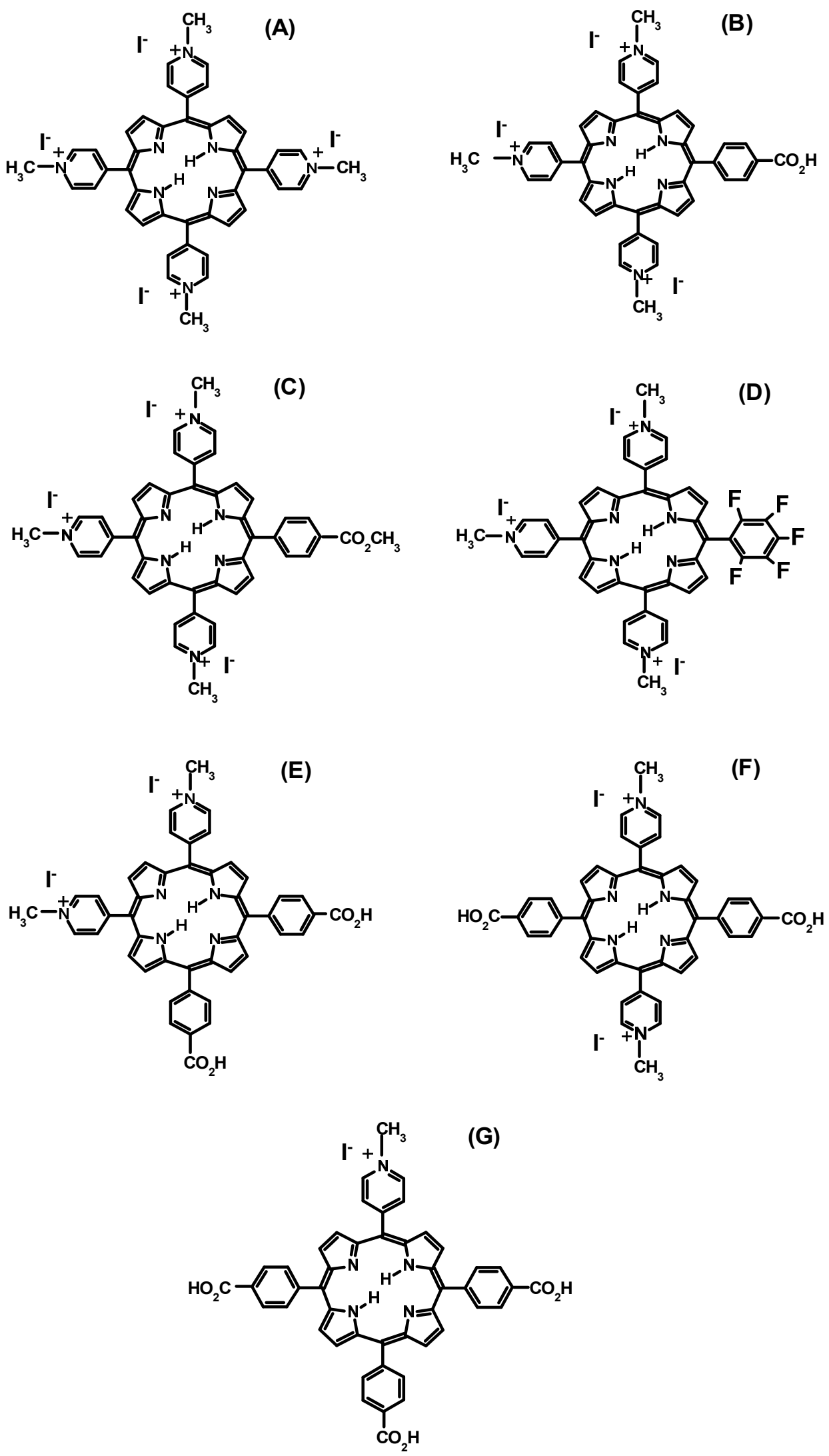

Figure 13. Structures of some cationic porphyrin derivatives. (A) Tetra-Py ${ }^{+} \mathrm{Me} ;(\mathbf{B}) \mathrm{Tri}-\mathrm{Py}{ }^{+}-\mathrm{Me}^{-} \mathrm{CO}_{2} \mathrm{H}$; (C) Tri-Py ${ }^{+}-\mathrm{Me}_{-} \mathrm{CO}_{2} \mathrm{CH}_{3}$; (D) Tri-Py ${ }^{+}-\mathrm{Me}-\mathrm{PF}_{4}$; (E) Di-Py $-\mathrm{Me}-\mathrm{Di}-\mathrm{CO}_{2} \mathrm{H}$ adj; (F) Di-Py ${ }^{+}-\mathrm{Me}-\mathrm{Di}-\mathrm{CO}_{2} \mathrm{H}$ opp; (G) Mono-Py ${ }^{+}-\mathrm{Me}-\mathrm{Tri}-\mathrm{CO}_{2} \mathrm{H}$; [142]. 
Almeida et al. [146] evaluated synergistic effect of PDI and antibiotics (ampicillin and chloramphenicol) on four multidrug-resistant (MDR) bacteria (E. coli, P. aeruginosa, A. baumannii, and S. aureus) in hospital wastewaters. A reduction of 6-8 $\log$ of the MDR bacteria was observed after 270 mins of irradiation with white light at $40 \mathrm{~W} \mathrm{~m}^{-2}$ with $5.0 \mu \mathrm{M}$ of the cationic porphyrin $\left(5,10,15,20\right.$-tetrakis( $N$-methylpyridinium-4-yl)porphyrin (Tetra-Py $\left.{ }^{+}-\mathrm{Me}\right)$. The presence of the antibiotics significantly enhanced the effectiveness of the PDI of the bacteria.

In another development, Alves [147,148] and coworkers used 5-pentafluorophenyl10,15,20-tri(4-pyridyl)porphyrin and the corresponding cationic 5,10,15-tris(1-methylpyridinium4-yl)-20-(pentafluorophenyl)porphyrin tri-iodide immobilized on cationized silica-coated magnetic nanoparticles of $\mathrm{Fe}_{3} \mathrm{O}_{4}$ and $\mathrm{CoFe}_{2} \mathrm{O}_{4}$ for water disinfection. Their results indicated that the cationic nanomagnet-porphyrin hybrids are highly efficient in bacterial destruction in water and wastewater treatment and support many photoinactivation cycles.

\section{Other Applications of Porphyrins}

Several porphyrins are now approved for a variety of diseases, including cancers [149-151] and age-related macular degeneration [152,153].

Porphyrin-based compounds have received significant importance in molecular electronics and supramolecular building blocks. Recent applications of porphyrin dyes for dye-sensitized solar cells have shown solar conversion efficiencies in silicon based photovoltaic devices $[154,155]$.

In addition, porphyrins are frequently used to build structures in supramolecular chemistry. For instance, a porphyrin-fullerene complex was involved in host-guest chemistry [156]. Vinodh et al. [157] reported recent developments in the synthesis of porphyrin assemblies associated with cyclodextrins, calixarenes, and resorcinarenes and their potential applications in the fields of molecular encapsulation/recognition, and chemical catalysis.

Also, porphyrins such as nickel and vanadyl porphyrins have been used to establish the biological origins of petroleum in organic geochemistry $[158,159]$.

\section{Side-Effects and Drawbacks of aPDT}

PDT has many side effects and drawbacks. These include optical absorption limitation. Light generated from standard laser and low-powered LED technology cannot penetrate more than $1 \mathrm{~cm}$ of tissue depth when it is used to activate photosensitizers. Thus, these light sources are less effective in treatment of systemic infections such as bacteremia and sepsis [160]. Another side effect of aPDT is post-therapeutic photosensitivity $[45,161]$. It cannot be used in patients sensitive to porphyrins and post-light therapy [162]. Moreover, the antibacterial effect stops when the light is turned off. Furthermore, non-specific localization of photosensitizers could lead to light-associated toxicity $[44,163,164]$.

\section{Future Perspective and Directions of aPDT}

The clinical need for porphyrins and aPDT already exists in hospitals worldwide and their applications have been growing rapidly in recent times. However, to improve their continual use in the clinical environment, there are many factors of aPDT that need to be considered. Some of these include more efficient light-delivery systems, the physiochemical characteristics of the porphyrins, dose to be administered, rate of drug delivery, stability and ease of application, and clearance after use. In addition, the barrier properties of the target site and patient acceptability may also have some negative impact on antibacterial PDT. Deep treatments, using porphyrins that absorb in the NIR region of the spectrum, can be achieved by two-photon PDT and/or metronomic PDT. The former is based on the development of laser technology, which allows the application of short (approx. $100 \mathrm{fs}$ ) laser pulses with high peak power. Instead of one, two light photons are absorbed and each photon accounts for only half of the excitation energy. Metronomic PDT is based on the application of very low 
doses of porphyrins combined with low rates of irradiation lasting for extended periods of time [165]. The outcome is cell death by apoptosis with minimal tissue necrosis.

The efficiency of PDT could be significantly enhanced by using nanoparticles, which can improve the photosensitizer solubility in aqueous media, its photophysical properties, and selectivity to the target tissue [166]. Targeted delivery of porphyrins can be achieved by conjugation with antibodies, engineered synthesis of molecules with specific structure, and even by attachment of porphyrins to magnetic nanoparticles. In the latter case, an externally applied magnetic field directs the PS to the area of infection [167]. Another significance of PDT that requires further investigation is its effect on the host immune system [121]. To overcome some of these challenges, PDT needs commitment and funds [168]. Information about this technique should also be disseminated by arranging aPDT-oriented workshops for chemists, physicians, biologists, and clinicians.

\section{Conclusions}

Antibacterial photodynamic therapy as a non-toxic, non-invasive, and cost-effective method is at the forefront for the treatment of infectious diseases. It offers the potential to significantly improve the current means of antibiotic treatment and reduce potential future problems associated with antibiotic-resistant bacteria.

Author Contributions: All authors contributed extensively to the work presented in this paper. All authors discussed and commented on the manuscript at all stages. Writing-original draft preparation, B.M.A.-T.; writing-review and editing, S.P.S. and O.S.O.

Funding: This research was funded by National Research Foundation (NRF), South Africa under the Nanotechnology Flagship Programme (Grant no: 97983), Competitive Programme for Rated Researchers (Grant no: 106060), DST/NRF Collaborative Postgraduate Training programme (Grant no: 92553), the University of Johannesburg, South Africa, Faculty of Science Research Committee, and University research Committee, South Africa.

Acknowledgments: The authors will like to thank National Research Foundation (NRF), South Africa under the Nanotechnology Flagship Programme (Grant no: 97983), Competitive Programme for Rated Researchers (Grant no: 106060), DST/NRF Collaborative Postgraduate Training programme (Grant no: 92553), the University of Johannesburg, South Africa, Faculty of Science Research Committee, and University research Committee, South Africa for financial support. B.M.A.T acknowledges Niger Delta University, Wilberforce Island, Nigeria for study leave granted.

Conflicts of Interest: The authors declare no conflict of interest.

\section{References}

1. Almeida, A.; Cunha, A.; Faustino, M.A.F.; Tomé, A.C.; Neves, M.G.P.M.S. Porphyrins as Antimicrobial Photosensitizing Agents. In Photodynamic Inactivation of Microbial Pathogens: Medical and Environmental Applications; Hamblin, M.R., Jori, G., Eds.; RSC Publishing: Cambridge, UK, 2011; Volume 11, pp. 83-160, ISBN 978-1-84973-144-7.

2. Maisch, T.; Hackbarth, S.; Regensburger, J.; Felgenträger, A.; Bäumler, W.; Landthaler, M.; Röder, B. Photodynamic inactivation of multi resistant bacteria (PIB)-a new approach to treat superficial infections in the 21st century. J. Dtsch. Dermatologischen Ges. 2011, 9, 360-366. [CrossRef] [PubMed]

3. Carrel, M.; Perencevich, E.N.; David, M.Z. USA 300 methicillin-resistant Staphylococcus aureus, United States, 2000-2013. Emerg Infect. Dis. 2015, 21, 1973-1980. [CrossRef] [PubMed]

4. Pollack, A. Rising Threat of Infections Unfazed by Antibiotics, New York Times. Available online: http: //www.biocence.com/download/raging_antibiotic.pdf (accessed on 11 November 2018).

5. Songca, S.P.; Oluwafemi, O.S. Photodynamic therapy: A new light for the developing world. Afr. J. Biotechnol. 2013, 12, 3590-3599. [CrossRef]

6. Obiero, C.W.; Seale, A.C.; Berkley, J.A. Empiric Treatment of Neonatal Sepsis in Developing Countries. Paediatr. Infect. Dis. J. 2015, 34, 659-661. [CrossRef] [PubMed]

7. Whitelaw, A. Hospital Acquired Infections. Available online: http://m.news24.com/health24/Medical/ Diseases/Hospital-Acquired-Infections-20120721 (accessed on 11 November 2018). 
8. Wise, R.J. The urgent need for new antibacterial agents. J. Antimicrob. Chemother. 2011, 66, 1939-1940. [CrossRef] [PubMed]

9. Cotter, P.D.; Ross, R.P.; Hill, C. Bacteriocins-A viable alternative to antibiotics? Nat. Rev. Microbiol. 2013, 11, 95-105. [CrossRef]

10. Tegos, G.P.; Hamblin, M.R. Disruptive innovations, new anti-infectives in the age of resistance. Curr. Opin. Pharmacol. 2013, 13, 673-677. [CrossRef] [PubMed]

11. Hamblin, M. Antimicrobial photodynamic inactivation: A bright new technique to kill resistant microbes. Curr. Opin. Microbiol. 2016, 33, 67-73. [CrossRef]

12. Liu, Y.; Qin, R.; Zaat, S.A.J.; Breukink, E.; Heger, M. Antibacterial photodynamic therapy: Overview of a promising approach to fight antibiotic-resistant bacterial infections. J. Clin. Trans. Res. 2015, 1, 140-167. [CrossRef]

13. Wainwright, M.; Maisch, T.; Nonell, S.; Plaetzer, K.; Almeida, A.; Tegos, G.P.; Hamblin, M.R. Photo antimicrobials-are we afraid of the light. Lancet Infect. Dis. 2017, 17, e49-e55. [CrossRef]

14. Garcez, A.S.; Núñez, S.C. Bacterial reduction in root canals using antimicrobial photodynamic therapy. In Lasers in Dentistry: Guide for Clinical Practice; de Freitas, P.M., Simões, A., Eds.; John Wiley \& Sons, Inc.: Hoboken, NJ, USA, 2015; pp. 131-138, ISBN 978-1-118-27502-3.

15. Chitsazi, M.T.; Shirmohammadi, A.; Pourabbas, R.; Abolfazli, N.; Farhoudi, I.; Azar, B.D.; Farhadi, F. Clinical and Microbiological Effects of Photodynamic Therapy Associated with Non-surgical Treatment in Aggressive Periodontitis. J. Dent. Res. Dent. Clin Dent. Prospect. 2014, 8, 153-159. [CrossRef] [PubMed]

16. Moreira, A.L.; Novaes, A.B., Jr.; Grisi, M.F.; Taba, M., Jr.; Souza, S.L.; Palioto, D.B.; de Oliveira, P.G.; Casati, M.Z.; Casarin, R.C.; Messora, M.R. Antimicrobial Photodynamic Therapy as an Adjunct to Non-Surgical Treatment of Aggressive Periodontitis: A Split-Mouth Randomized Controlled Trial. J. Periodontol. 2015, 86, 376-386. [CrossRef] [PubMed]

17. Garcia, V.G.; de Lima, M.A.; Okamoto, T.; Milanezi, L.A.; Júnior, E.C.G.; Fernandes, L.A.; de Almeida, J.M.; Theodoro, L.H. Effect of photodynamic therapy on the healing of cutaneous third-degree-burn: Histological study in rats. Lasers Med. Sci. 2010, 25, 221-228. [CrossRef] [PubMed]

18. Alves, E.; Faustino, M.A.; Tomé, J.P.; Neves, M.G.; Tomé, A.C.; Cavaleiro, J.A.; Cunha, Â.; Gomes, N.C.; Almeida, A. Photodynamic antimicrobial chemotherapy in aquaculture: Photoinactivation studies of Vibrio fischeri. PLoS ONE 2011, 6, 1-9. [CrossRef] [PubMed]

19. Yuan, Y.; Liu, Z.-Q.; Jin, H.; Sun, S.; Liu, T.-J.; Wang, X.; Fan, H.-J.; Hou, S.-K.; Ding, H. Photodynamic antimicrobial chemotherapy with the novel amino acid-porphyrin conjugate $4 \mathrm{I}$ : In vitro and in vivo studies. PLoS ONE 2017, 12, e0176529-e0176541. [CrossRef] [PubMed]

20. Arredondo-Espinoza, E.; López-Cortina, S.; Balderas-Rentería, I. Synthesis and Photodynamic Activity of 5, 10, 15-Tris (p-chlorophenyl)-20-(2- hydroxy-3-methoxyphenyl)-21H, 23H-porphyrin. J. Mex. Chem. Soc. 2014, 58, 369-373.

21. Cieplik, F.; Pummer, A.; Regensburger, J.; Hiller, K.A.; Späth, A.; Tabenski, L.; Buchalla, W.; Maisch, T. The impact of absorbed photons on antimicrobial photodynamic efficacy. Front. Microbiol. 2015, 6, 1-10. [CrossRef]

22. Hashimoto, M.C.; Prates, R.A.; Kato, I.T.; Núñez, S.C.; Courrol, L.C.; Ribeiro, M.S. Antimicrobial photodynamic therapy on drug-resistant Pseudomonas aeruginosa-induced infection. An in vivo study. Photochem. Photobiol. 2012, 88, 590-595. [CrossRef]

23. Allison, R.R.; Moghissi, K. Photodynamic Therapy (PDT): PDT Mechanisms. Clin. Endosc. 2013, 46, $24-29$. [CrossRef]

24. Nitzan, Y.; Gutterman, M.; Malik, Z.; Ehrenberg, B. Inactivation of gram-negative bacteria by photosensitized porphyrin. Photochem. Photobiol. 1992, 55, 89-96. [CrossRef]

25. Jori, G.; Fabris, C.; Soncin, M.; Ferro, S.; Coppellotti, O.; Dei, D.; Fantetti, L.; Chiti, G.; Roncucci, G. Photodynamic therapy in the treatment of microbial infections: Basic principles and perspective applications. Lasers Surg. Med. 2006, 38, 468-481. [CrossRef] [PubMed]

26. Malatesti, N.; Munitic, I.; Jurak, I. Porphyrin-based cationic amphiphilic photosensitisers as potential anticancer, antimicrobial and immunosuppressive agents. Biophys. Rev. 2017, 9, 149-168. [CrossRef] [PubMed]

27. Calzavara-Pinton, P.G.; Szeimies, R.M.; Ortel, B. Photodynamic Therapy and Fluorescence Diagnosis in Dermatology; Elsevier: Amsterdam, The Netherlands, 2001; ISBN 9780080538846. 
28. MacRobert, A.J.; Bown, S.G.; Phillips, D. What are the ideal photoproperties for a sensitizer? Ciba Found. Symp. 1989, 14, 4-12.

29. Castano, A.P.; Demidova, T.N.; Hamblin, M.R. Mechanisms in photodynmic therapy. Part one -photosensitizers, photochemistry and cellular localization. Photodiagn. Photodyn. Ther. 2004, 1, $279-293$. [CrossRef]

30. Omar, G.S.M. Killing of Organisms Responsible for Wound Infections Using a Light-Activated Antimicrobial Agent. Ph.D. Thesis, University College, London, UK, 2010.

31. Mojzisova, H.; Bonneau, S.; Brault, D. Structural and physico-chemical determinants of the interactions of macrocyclic photosensitizers with cells. Eur. Biophys. J. 2007, 36, 943-953. [CrossRef] [PubMed]

32. MacDonald, I.J.; Dougherty, J. Basic principles of photodynamic therapy. J. Porphyr. Phthalocyanines 2001, 5, 105-129. [CrossRef]

33. Luksiene, Z. Photodynamic therapy: Mechanism of action and ways to improve the efficiency of treatment. Medicina 2003, 39, 1137-1150. [PubMed]

34. Alves, E.; Faustino, M.A.; Tomé, J.P.; Neves, M.G.; Tomé, A.C.; Cavaleiro, J.A.; Cunha, Â.; Gomes, N.C.; Almeida, A. Nucleic acid changes during photodynamic inactivation of bacteria by cationic porphyrins. Bioorg. Med. Chem. 2013, 21, 4311-4318. [CrossRef] [PubMed]

35. Wainwright, M.; Crossley, K.B. Photosensitising agents-Circumventing resistance and breaking down biofilms: A review. Int. Biodeterior. Biodegrad. 2004, 53, 119-126. [CrossRef]

36. Maclean, M.; MacGregor, S.J.; Anderson, J.G.; Woolsey, G.A. The role of oxygen in the visible-light inactivation of Staphylococcus aureus. J. Photochem. Photobiol. 2008, 92, 180-184. [CrossRef]

37. Alves, E.; Faustino, M.A.F.; Neves, M.G.P.M.S.; Cunha, A.; Tomé, J.P.C.; Almeida, A. An insight on bacterial cellular targets of photodynamic inactivation. Future Med. Chem. 2014, 6, 141-164. [CrossRef] [PubMed]

38. Kim, S.Y.; Kwon, O.J.; Park, J.W. Inactivation of catalase and superoxide dismutase by singlet oxygen derived from photoactivated dye. Biochimie 2001, 83, 437-444. [CrossRef]

39. Planas, O.; Boix-Garriga, E.; Rodríguez-Amigo, B.; Torra, J.; Bresolí-Obach, R.; Flors, C.; Viappiani, C.; Agut, M.; Ruiz-González, R.; Nonell, S. Chapter 9: Newest approaches to singlet oxygen photosensitisation in Biological Media. In Photochemistry; Fasani, E., Albini, A., Eds.; Royal Society of Chemistry: Cambridge, UK, 2015; Volume 42, pp. 233-278, ISBN 978-1-84973-956-6.

40. Milgrom, L. The Colours of Life: An Introduction to the Chemistry of Porphyrins and Related Compounds; Oxford University Press: New York, NY, USA, 1997; pp. 66-99, ISBN1 0198553803, ISBN2 9780198553809.

41. Dolphin, D. The Porphyrins, Volumes 1-7; Academic Press: New York, NY, USA, 1978; pp. 740-810, ISBN 0-12-220107-8.

42. Wijesekera, T.P.; Dolphin, D. Some preparations and properties of porphyrins. In Methods in Porphyrin Photosensitization; Springer: Boston, MA, USA, 1985; pp. 229-266, ISBN 978-1-4612-9276-0.

43. Geier, R. Available online: http://www.colgate.edu/facultysearch/facultydirectory/ggeier (accessed on 11 November 2018).

44. Connor, A.E.O.; Gallagher, W.M.; Byrne, A.T. Porphyrin and Non-porphyrin Photosensitizers in Oncology: Preclinical and Clinical Advances in Photodynamic Therapy. Photochem. Photobiol. 2009, 85, 1053-1074. [CrossRef]

45. Schuitmaker, J.J.; Baas, P.; van Leengoed, H.L.; van der Meulen, F.W.; Star, W.M.; van Zandwijk, N. Photodynamic therapy: A promising new modality for the treatment of cancer. J. Photochem. Photobiol. B Biol. 1996, 34, 3-12. [CrossRef]

46. Mccarthy, J.R.; Bhaumik, J.; Merbouh, N.; Weissleder, R. High-yielding syntheses of hydrophilic conjugatable chlorins and bacteriochlorins. Org. Biomol. Chem. 2009, 7, 3430-3436. [CrossRef] [PubMed]

47. Sternberg, E.D.; Dolphin, D.; Brückner, C. Porphyrin-based photosensitizers for use in photodynamic therapy. Tetrahedron 1998, 54, 4151-4202. [CrossRef]

48. Embleton, M.L.; Nair, S.P.; Heywood, W.; Menon, D.C.; Cookson, B.D.; Wilson, M. Development of a novel targeting system for lethal photosensitization of antibiotic-resistant strains of Staphylococcus aureus. Antimicrob. Agents Chemother. 2005, 49, 3690-3696. [CrossRef] [PubMed]

49. Lindsey, J.S. Synthesis of meso-substituted porphyrins. In The Porphyrin Handbook; Kadish, M., Smith, K.M., Guilard, R., Eds.; Academic Press: San Diego, CA, USA, 2000; ISBN 0-12-393200-9.

50. Rothemund, P.; Menotti, A.R. Porphyrin Studies. IV. The Synthesis of $\alpha, \beta, \gamma, \delta$-Tetraphenylporphine. J. Am. Chem Soc. 1941, 63, 267-270. [CrossRef] 
51. Adler, A.D.; Longo, F.R.; Finarelli, J.D.; Goldmacher, J.; Assour, J.; Korsakoff, L. A simplified synthesis for meso-tetraphenylporphin. J. Org. Chem. 1967, 32, 476. [CrossRef]

52. Boens, B.; Faugeras, P.A.; Vergnaud, J.; Lucas, R.; Teste, K.; Zerrouki, R. Iodine-catalyzed one-pot synthesis of unsymmetrical meso-substituted porphyrins. Tetrahedron 2010, 66, 1994-1996. [CrossRef]

53. Kappe, C.O.; Stadler, A.; Dalinger, D. Microwaves in Organic and Medicinal Chemistry, 2nd ed.; Wiley-VCH: Weinheim, Germany, 2012; ISBN1 3527331859, ISBN2 9783527331857.

54. Pinto, S.M.; Henriques, C.A.; Tomé, V.A.; Vinagreiro, C.S.; Calvete, M.J.; Dąbrowski, J.M.; Piñeiro, M.; Arnaut, L.G.; Pereira, M.M. Synthesis of meso-substituted porphyrins using sustainable chemical processes. J. Porphyr. Phthalocyanines 2016, 20, 45-60. [CrossRef]

55. Naik, R.; Joshi, P.; Kaiwar Deshpande, R.K. Facile synthesis of mesosubstituted dipyrromethanes and porphyrins using cation exchange resin. Tetrahedron 2003, 59, 2207-2213. [CrossRef]

56. Nia, S.; Gong, X.; Drain, C.M.; Jurow, M.; Rizvi, W.; Qureshy, M.J. Solvent-free synthesis of meso-tetraarylporphyrins in air: Product, diversity and yield optimization. J. Porphyr. Phthalocyanines 2010, 14, 621-629. [CrossRef]

57. Babu, M.M.; Amaravathi, M.L.; Giribabu, L.G.; Chandramouli, G. Synthesis of meso-substituted porphyrins in room temperature ionic liquid. J. Chem Res. Synop. 2008, 11, 666-668. [CrossRef]

58. Mondal, D.; Bera, S. Porphyrins and phthalocyanines: Promising molecules for light-triggered antibacterial nanoparticles. Adv. Nat. Sci. Nanosci. Nanotechnol. 2014, 5, 1-14. [CrossRef]

59. Lammer, A.D.; Cook, M.E.; Sessler, J.L. Synthesis and anti-cancer activities of a water-soluble gold (III) porphyrin. J. Porphyr. Phthalocyanines 2015, 19, 398-403. [CrossRef] [PubMed]

60. Abrahamse, H.; Hamblin, M.R. New photosensitizers for photodynamic therapy. Biochem. J. 2016, 473, 347-364. [CrossRef]

61. Kou, J.; Dou, D.; Yang, L. Porphyrin photosensitizers in photodynamic therapy and its Applications. Oncotarget 2017, 8, 81591-81603. [CrossRef]

62. Nyman, E.S.; Hynninen, P.H. Research advances in the use of tetrapyrrolic photosensitizers for photodynamic therapy. J. Photochem. Photobiol. B 2004, 73, 1-28. [CrossRef]

63. Singh, S.; Aggarwal, A.; Bhupathiraju, N.D.K.; Arianna, G.; Tiwari, K.; Drain, C.M. Glycosylated porphyrins, phthalocyanines, and other porphyrinoids for diagnostics and therapeutics. Chem. Rev. 2015, 115, 10261-10306. [CrossRef]

64. Stojiljkovic, I.; Evavold, B.D.; Kumar, V. Antimicrobial properties of porphyrins. Expert Opin. Invest. Drugs 2001, 10, 309-320. [CrossRef] [PubMed]

65. Khan, H.A.; Ahmad, A.; Mehboob, R. Nosocomial infections and their control strategies. Asia-Pac. J. Trop. Biomed. 2015, 5, 509-514. [CrossRef]

66. Bruckner, M.Z. Gram staining. Microbial Life Educational Resources. 2016. Available online: http://serc.carleton. edu/microbelife/research_methods/microscopy/gramstain.html (accessed on 11 November 2018).

67. Banfi, S.; Caruso, E.; Buccafurni, L.; Battini, V.; Zazzaron, S.; Barbieri, P.; Orlandi, V. Antibacterial activity of tetraaryl-porphyrin photosensitizers: An in vitro study on Gram negative and Gram-positive bacteria. J. Photochem. Photobiol. B 2006, 85, 28-38. [CrossRef] [PubMed]

68. Prasanth, C.S.; Karunakaran, S.C.; Paul, A.K.; Kussovski, V.; Mantareva, V.; Ramaiah, D.; Selvaraj, L.; Angelov, I.; Avramov, L.; Nandakumar, K.; et al. Antimicrobial photodynamic efficiency of novel cationic porphyrins towards periodontal gram- positive and Gram (-) pathogenic bacteria. Photochem. Photobiol. 2014, 90, 628-640. [CrossRef] [PubMed]

69. Bertoloni, G.; Rossi, F.; Valduga, G.; Jori, G.; Vanlier, J. Photosensitizing activity of water-soluble and lipid-soluble phthalocyanines on Escherichia coli. FEMS Microbiol. Lett. 1990, 71, 149-155. [CrossRef] [PubMed]

70. Malik, Z.; Ladan, H.; Nitzan, Y. Photodynamic inactivation of gram-negative bacteria-Problems and possible solutions. J. Photochem. Photobiol. B 1992, 14, 262-266. [CrossRef]

71. Rovaldi, C.R.; Pievsky, A.; Sole, N.A.; Friden, P.M.; Rothstein, D.M.; Spacciapoli, P. Photoactive porphyrin derivative with broad-spectrum activity against oral pathogens in vitro. Antimicrob. Agents Chemother. 2000, 44, 3364-3367. [CrossRef] [PubMed]

72. Hamblin, M.R.; O’Donnell, D.A.; Murthy, N.; Rajagopalan, K.; Michaud, N.; Sherwood, M.E.; Hasan, T. Polycationic photosensitizer conjugates: Effects of chain length and Gram classification on the photodynamic inactivation of bacteria. J. Antimicrob. Chemother. 2002, 49, 941-951. [CrossRef] 
73. Verma, S.; Sallum, U.W.; Athar, H.; Rosenblum, L.; Foley, J.W.; Hasan, T. Antimicrobial photodynamic efficacy of side-chain functionalized benzo[a]phenothiazinium dyes. Photochem. Photobiol. 2009, 85, 111-118. [CrossRef] [PubMed]

74. Grinhol, M.; Szramka, B.; Olender, K.A.; Graczyk, A. Bactericidal effect of photodynamic therapy against methicillin-resistant Staphylococcus aureus strain with the use of various porphyrin photosensitizers. Acta Biochim. Pol. 2007, 54, 665-670.

75. Embleton, M.L.; Nair, S.P.; Cookson, B.D.; Wilson, M. Antibody-directed photodynamic therapy of methicillin-resistant Staphylococcus aureus. Microb. Drug Resist. 2004, 10, 92-97. [CrossRef] [PubMed]

76. Hamblin, M.R.; Zahra, T.; Contag, C.H.; McManus, A.T.; Hasan, T. Optical monitoring and treatment of potentially lethal wound infections in vivo. J. Infect. Dis. 2003, 187, 1717-1725. [CrossRef] [PubMed]

77. Dai, T.; Huang, Y.Y.; Hamblin, M.R. Photodynamic therapy for localized infections-state of the art. Photodiagn. Photodyn. Ther. 2009, 6, 170-188. [CrossRef] [PubMed]

78. Larson, R.A.; Marley, K.A. Oxidative mechanisms of phototoxicity. In Environmental Oxidants; Nriagu, J.O., Simmons, M.S., Eds.; John Wiley \& Sons: New York, NY, USA, 1994; pp. 269-318, ISBN1 0471579289 , ISBN2 9780471579281.

79. Gonzalez-Delgado, J.A.; Kennedy, P.J.; Ferreira, M.; Tome, J.P.C.; Samento, B. Use of Photosensitizers in Semisolid Formulations for Microbial Photodynamic Inactivation. J. Med. Chem. 2016, 59, 4428-4442. [CrossRef] [PubMed]

80. Valduga, G.; Bertoloni, G.; Reddi, E.; Jori, G. Effect of extracellularly generated singlet oxygen on gram-positive and gram-negative bacteria. J. Photochem. Photobiol. B 1993, 21, 81-86. [CrossRef]

81. Bhatti, M.; Nair, S.P.; Macrobert, A.J.; Henderson, B.; Shepherd, P.; Cridland, J.; Wilson, M. Identification of photolabile outer membrane proteins of Porphyromonas gingivalis. Curr. Microbiol. 2001, 43, 96-99. [CrossRef] [PubMed]

82. Ragàs, X.; He, X.; Agut, M.; Roxo-Rosa, M.; Gonsalves, A.R.; Serra, A.C.; Nonell, S. Singlet Oxygen in Antimicrobial Photodynamic Therapy: Photosensitizer-Dependent Production and Decay in E. coli. Molecules 2013, 18, 2712-2725. [CrossRef]

83. Jori, G.; Roncucci, G. Photodynamic Therapy in Microbial Infections. Adv. Clin. Exper. Med. 2006, 15, 421-426.

84. Salton, M.R.J. Structure and function of bacterial cell membranes. Ann. Rev. Microbiol. 1967, 21, 417-442. [CrossRef]

85. Gábor, K.; Szocs, K.; Maillard, P.; Csik, G. Photobiological activity of exogenous and endogenous porphyrin derivatives in Escherichia coli and Enterococcus hirae cells. Radiat. Environ. Biophys. 2001, 40, 145-151. [CrossRef]

86. Hoque, J.; Akkapeddi, P.; Yadav, V.; Manjunath, G.B.; Uppu, D.S.; Konai, M.M.; Yarlagadda, V.; Sanyal, K.; Haldar, J. Broad spectrum antibacterial and antifungal polymeric paint materials: Synthesis, structure-activity relationship, and membrane-active mode of action. ACS Appl. Mater. Interfaces. 2015, 7, 1804-1815. [CrossRef] [PubMed]

87. Egyeki, M.; Turóczy, G.; Majer, Z.; Tóth, K.; Fekete, A.; Maillard, P.; Csık, G. Photosensitized inactivation of T7 phage as surrogate of non-enveloped DNA viruses: Efficiency and mechanism of action. Biochim. Biophys. Acta 2003, 1624, 115-124. [CrossRef] [PubMed]

88. Winckler, K.D. Special section: Focus on anti-microbial photodynamic therapy (PDT). J. Photochem. Photobiol. B 2007, 86, 43-44. [CrossRef] [PubMed]

89. Niemz, N.H. Laser-tissue interactions. Fundamentals and Applications, 3rd ed.; Springer: New York, NY, USA, 2007; pp. 19-25, ISBN1 3540721916, ISBN2 9783540721918.

90. Brancaleon, L.; Moseley, H. Laser and non-laser light sources for photodynamic therapy. Lasers Med. Sci. 2002, 17, 173-186. [CrossRef] [PubMed]

91. Calin, M.A.; Parasca, S.V. Light sources for photodynamic inactivation of bacteria. Lasers Med. Sci. 2009, 24, 453-460. [CrossRef] [PubMed]

92. Wilson, B.; Patterson, M.S. The physics, biophysics and technology of photodynamic therapy. Phys. Med. Biol. 2008, 53, R61-R109. [CrossRef] [PubMed]

93. Mitton, D.; Ackroyd, R. A brief overview of photodynamic therapy in Europe. Photodiagn. Photodyn. Ther. 2008, 5, 103-111. [CrossRef] [PubMed] 
94. Caminos, D.A.; Spesia, M.B.; Durantini, E.N. Photodynamic inactivation of Escherichia coli by novel meso-substituted porphyrins by 4-(3-N,N,N-trimethy-lammoniumpropoxy)phenyl and 4-(trifluoromethyl)phenyl groups. Photochem. Photobiol. Sci. 2006, 5, 56-65. [CrossRef] [PubMed]

95. Thakuri, P.S.; Joshi, R.; Basnet, S.; Pandey, S.; Taujale, S.D.; Mishra, N. Antibacterial photodynamic therapy on Staphylococcus aureus and Pseudomonas aeruginosa in-vitro. Nepal Med. Coll. J. 2011, 13, 281-284.

96. Luksiene, Z. New approach to inactivation of harmful and pathogenic microorganisms by photosensitization. Food Technol. Biotechnol. 2005, 43, 411-418.

97. Orenstein, A.; Klein, D.; Kopolovic, J.; Winkler, E.; Malik, Z.; Keller, N.; Nitzan, Y. The use of porphyrins for eradication of Staphylococcus aureus in burn wound infections. FEMS Immunol. Med. Microbiol. 1997, 19, 307-314. [CrossRef]

98. Zoltan, T.; Vargas, F.; Rivas, C.; López, V.; Perez, J.; Biasutto, A. Synthesis, Photochemical and Photoinduced Antibacterial Activity Studies of meso-Tetra(pyren-1-yl)porphyrin and its Ni, Cu and Zn Complexes. Sci. Pharm. 2010, 78, 767-789. [CrossRef] [PubMed]

99. Tavares, A.; Dias, S.R.; Carvalho, C.M.; Faustino, M.A.; Tomé, J.P.; Neves, M.G.; Tomé, A.C.; Cavaleiro, J.A.; Cunha, Â.; Gomes, N.C.; et al. Mechanisms of photoinactivation of Gram-negative recombinant bioluminescent bacteria by cationic porphyrins. Photochem. Photobiol. Sci. 2011, 10, 1659-1669. [CrossRef]

100. Maish, T.; Bosl, C.; Szeimies, R.M.; Love, B.; Abels, C. Determination of the antimicrobial efficacy of a new porphyrin-based photosensitizer against MRSA ex vivo. Photochem. Photobiol. Sci. 2007, 6, 545-551. [CrossRef] [PubMed]

101. Taub, A.F. Photodynamic therapy: Other uses. Dermatol Clin. 2007, 25, 101-109. [CrossRef] [PubMed]

102. Nitzan, Y.; Ashkenazi, H. Photoinactivation of Deinococcus radiodurans: An Unusual Gram-Positive Microorganism. Photochem. Photobiol. 1999, 69, 505-510. [CrossRef]

103. Nitzan, Y.; Ashkenazi, H. Photoinactivation of Acinetobacter baumannii and Escherichia coli B by a Cationic Hydrophilic Porphyrin at Various Light Wavelengths. Curr. Microbiol. 2001, 42, 408-414. [CrossRef] [PubMed]

104. Maisch, T.; Szeimies, R.M.; Lehn, N.; Abels, C. Antibacterial photodynamic therapy. A new treatment for bacterial skin diseases? Hautarzt 2005, 56, 1048-1055. [CrossRef]

105. Hanakova, A.; Bogdanova, K.; Tomankova, K.; Pizova, K.; Malohlava, J.; Binder, S.; Bajgar, R.; Langova, K.; Kolar, M.; Mosinger, J.; et al. The application of antimicrobial photodynamic therapy on S. aureus and E. coli using porphyrin photosensitizers bound to cyclodextrin. Microbiol. Res. 2014, 16, 163-170. [CrossRef]

106. Ruiz-González, R.; Montserrat, A.; Reddi, E.; Nonell, S. A Comparative Study on Two Cationic Porphycenes: Photophysical and Antimicrobial Photoinactivation Evaluation. Int. J. Mol. Sci. 2015, 16, 27072-27086. [CrossRef]

107. Wikene, K.O.; Bruzell, E.; Tønnesen, H.H. Improved antibacterial phototoxicity of a neutral porphyrin in natural deep eutectic solvents. J. Photochem. Photobiol. B 2015, 148, 188-196. [CrossRef] [PubMed]

108. Rahimi, R.; Fayyaza, F.; Rassab, M.; Rabbania, M. Microwave-assisted synthesis of 5,10,15,20-tetrakis(4-nitrophenyl)porphyrin and zinc derivative and study of their bacterial photoinactivation. Iran. Chem. Commum. 2015, 4, 175-185.

109. Lambrechts, S.A.G.; Demidova, T.N.; Aalders, M.C.G.; Hasan, T.; Hamblin, M.R. Photodynamic therapy for Staphylococcus aureus infected burn wounds in mice. Photochem. Photobiol. Sci. 2005, 4, 503-509. [CrossRef] [PubMed]

110. Dia, T.; Tegos, G.P.; Zhiyentayev, T.; Mylonakis, E.; Hamblin, M.R. Photodynamic therapy for methicillin-resistant Staphylococcus aureus infection in a mouse skin abrasion model. Lasers Surg. Med. 2010, 42, 38-44. [CrossRef]

111. Tavares, A.; Carvalho, C.; Faustino, M.A.; Neves, M.G.; Tomé, J.P.; Tomé, A.C.; Cavaleiro, J.A.; Cunha, Â.; Gomes, N.; Alves, E.; et al. Antimicrobial photodynamic therapy: Study of bacterial recovery viability and potential development of resistance after treatment. Mar. Drugs 2010, 8, 91-105. [CrossRef]

112. Costa, L.; Tomé, J.P.; Neves, M.G.; Tomé, A.C.; Cavaleiro, J.A.; Faustino, M.A.; Cunha, Â.; Gomes, N.C.; Almeida, A. Evaluation of resistance development and viability recovery by T4-like bacteriophages after repeated cycles of aPDT. Antivir Res. 2011, 91, 278-282. [CrossRef]

113. Wardlaw, J.L.; Sullivan, T.J.; Lux, C.N.; Austin, F.W. Photodynamic therapy against common bacteria causing wound and skin infections. Vet. J. 2011, 192, 374-377. [CrossRef] 
114. O'Riordan, K.; Akilov, O.E.; Hasan, T. The potential for photodynamic therapy in the treatment of localized infections. Photodiagn. Photodyn. Ther. 2005, 2, 247-262. [CrossRef]

115. Songca, S.P. Photodynamic Therapy for the Developing World. In Professorial Inaugural Lecture; Walter Sisulu University: Mthatha, South Africa, 2010; p. 22.

116. Babilas, P.; Schreml, S.; Landthaler, M.; Szeimies, R.M. Photodynamic therapy in dermatology: State-of-the-art. Photodermatol. Photoimmunol. Photomed. 2010, 26, 118-132. [CrossRef]

117. Gold, M.H. Photodynamic Therapy in Dermatology; Springer: New York, NY, USA, 2011; p. 181, ISBN1 1441912983, ISBN2 9781441912985.

118. Wan, M.T.; Lin, J.Y. Current evidence and applications of photodynamic therapy in dermatology. Clin. Cosmet. Investig. Dermatol. 2014, 7, 145-163. [CrossRef]

119. Gursoy, H.; Ozcakir-Tomruk, C.; Tanalp, J.; Yilmaz, S. Photodynamic therapy in dentistry: A literature review. Clin. Oral Investig. 2013, 17, 1113-1125. [CrossRef] [PubMed]

120. Sculean, A.; Aoki, A.; Romanos, G.; Schwarz, F.; Miron, R.J.; Cosgarea, R. Is Photodynamic Therapy an Effective Treatment for Periodontal and Peri-Implant Infections? Dent. Clin. North Am. 2015, 59, 831-858. [CrossRef] [PubMed]

121. Kharkwal, G.B.; Sharma, S.K.; Huang, Y.Y.; Dai, T.; Hamblin, M.R. Photodynamic therapy for infections: Clinical applications. Lasers Surg. Med. 2011, 43, 755-767. [CrossRef] [PubMed]

122. Sperandio, F.F.; Huang, Y.Y.; Hamblin, M.R. Antimicrobial photodynamic therapy to kill Gram-negative bacteria. Recent Patent. Anti-infect. Drug Discov. 2013, 8, 108-120. [CrossRef]

123. Robson, M.C.; Mannari, R.J.; Smith, P.D.; Payne, W.G. Maintenance of wound bacterial balance. Am. J. Surg. 1999, 178, 399-402. [CrossRef]

124. Grinholc, M.; Rapacka-Zdonczyk, A.; Rybak, B.; Szabados, F.; Bielawski, K.P. Multi- resistant strains are as susceptible to photodynamic inactivation as their naïve counterparts: Protoporphyrin IX-mediated photoinactivation reveals differences between methicillin-resistant and methicillin-sensitive Staphylococcus aureus strains. Photomed Laser Surg. 2014, 32, 121-129. [CrossRef] [PubMed]

125. Fayyaz, F.; Rahimi, R.; Rassa, M.; Yaghoobi, R.H. Photodynamic Antimicrobial Chemotherapy, A Pathway for Photo-Inactivation of Bacteria by Porphyrin Compounds. In Proceedings of the 1st International Electronic Conference on Molecular Science: Cell Signaling, Survival and Growth. Sciforum Electronic Conference Series 1, Basel, Switzerland, 15-22 October 2015; p. b003. [CrossRef]

126. Barra, F.; Roscetto, E.; Soriano, A.A.; Vollaro, A.; Postiglione, I.; Pierantoni, G.M.; Palumbo, G.; Catania, M.R. Photodynamic and Antibiotic Therapy in Combination to Fight Biofilms and Resistant Surface Bacterial Infections. Int. J. Mol. Sci. 2015, 16, 20417-20430. [CrossRef] [PubMed]

127. Bartolomeu, M.; Rocha, S.; Cunha, A.; Neves, M.G.P.M.S.; Faustino, M.A.F.; Almeida, A. Effect of Photodynamic Therapy on the Virulence Factors of Staphylococcus aureus. Front. Microbiol. 2016, 7, 1-11. [CrossRef] [PubMed]

128. Bojar, R.A.; Holland, K.T. Acne and Propionibacterium acne. Clin. Dermatol. 2004, 22, 375-379. [CrossRef] [PubMed]

129. Farrar, M.D.; Ingham, E. Acne: Inflammation. Clin. Dermatol. 2004, 22, 380-384. [CrossRef] [PubMed]

130. Meffert, H.; Gaunitz, K.; Gutewort, T.; Amlong, U.J. Aknetherapie mit sichtbarem Licht. Verkürzung der Bestrahlungszeit durch Verwendung eines Hochdruckstrahlers vom Blaulichttyp. Dermatol. Monatsschr. 1990, 176, 597-603. [PubMed]

131. Kawada, A.; Aragane, Y.; Kameyama, H.; Sangen, Y.; Tezuka, T. Acne phototherapy with a high-intensity, enhanced, narrow-band, blue light source: An open study and in vitro investigation. J. Dermatol. Sci. 2002, 30, 129-135. [CrossRef]

132. Ashkenazi, H.; Malik, Z.; Harth, Y.; Nitzan, Y. Eradication of Propionibacterium acnes by its endogenic porphyrins after illumination with high intensity blue light. FEMS Immunol. Med. Microbiol. 2003, 35, 17-24. [CrossRef] [PubMed]

133. Schaller, M.; Loewenstein, M.; Borelli, C.; Jacob, K.; Vogeser, M.; Burgdorf, W.H.C.; Plewig, G. Induction of a chemoattractive proinflammatory cytokine response after stimulation of keratinocytes with Propionibacterium acnes and coproporphyrin III. Br. J. Dermatol. 2005, 153, 66-71. [CrossRef] [PubMed]

134. Wainwright, M.; Smalley, H.; Flint, C. The use of photosensitisers in acne treatment. J. Photochem. Photobiol. $B$ 2011, 105, 1-5. [CrossRef] [PubMed] 
135. Wilson, M. Susceptibility of oral bacteria biofilms to antimicrobial agents. J. Med. Microbiol. 1996, 44, 79-87. [CrossRef]

136. Garcia, V.G.; Júnior, G.; Clementino, E.; Fernandes, L.A.; Bosco, A.F.; Nagata, H.; José, M.; Casatti, C.A.; Ervolino, E.; Theodoro, L.H. Adjunctive Antimicrobial Photodynamic Treatment of Experimentally Induced Periodontitis in Rats with Ovariectomy. J. Periodontol. 2013, 84, 556-565. [CrossRef]

137. Takasaki, A.A.; Aoki, A.; Mizutani, K.; Schwarz, F.; Sculean, A.; Wang, C.Y.; Koshy, G.; Romanos, G.; Ishikawa, I.; Izumi, Y. Application of antimicrobial photodynamic therapy in periodontal and peri-implant diseases. Periodontol. 2000 2009, 5, 1-32. [CrossRef]

138. Cieplik, F.; Pummer, A.; Leibl, C.; Regensburger, J.; Schmalz, G.; Buchalla, W.; Hiller, K.A.; Maisch, T. Photodynamic inactivation of root canal bacteria by light activation through human dental hard and simulated surrounding tissue. Front. Microbiol. 2016, 7, 929. [CrossRef]

139. Jemli, M.; Alouini, Z.; Sabbahi, S.; Gueddari, M. Destruction of fecal bacteria in wastewater by three photosensitizers. J. Environ. Monit. 2002, 4, 511-516. [CrossRef]

140. Bonnett, R.; Krysteva, M.A.; Lalov, I.G.; Artarsky, S.V. Water disinfection using photosensitizers immobilized on chitosan. Water Res. 2006, 40, 1269-1275. [CrossRef] [PubMed]

141. Carvalho, C.M.; Gomes, A.T.; Fernandes, S.C.; Prata, A.C.; Almeida, M.A.; Cunha, M.A.; Tomé, J.P.; Faustino, M.A.; Neves, M.G.; Tomé, A.C.; et al. Photoinactivation of bacteria in wastewater by porphyrins: Bacterial $\beta$-galactosidase activity and leucine-uptake as methods to monitor the process. J. Photochem. Photobiol. B 2007, 88, 112-118. [CrossRef] [PubMed]

142. Alves, E.; Costa, L.; Carvalho, C.M.; Tomé, J.P.; Faustino, M.A.; Neves, M.G.; Tomé, A.C.; Cavaleiro, J.A.; Cunha, Â.; Almeida, A. Charge effect on the photoinactivation of Gram-negative and Gram-positive bacteria by cationic meso-substituted porphyrins. BMC Microbiol. 2009, 9, 1-13. [CrossRef] [PubMed]

143. Costa, L.; Alves, E.; Carvalho, C.M.; Tomé, J.P.; Faustino, M.A.; Neves, M.G.; Tomé, A.C.; Cavaleiro, J.A.; Cunha, Â.; Almeida, A. Sewage bacteriophage photoinactivation by cationic porphyrins: A study of charge effect. Photochem. Photobiol. Sci. 2008, 7, 415-422. [CrossRef] [PubMed]

144. Oliveira, A.; Almeida, A.; Carvalho, C.M.B.; Tomé, J.P.C.; Faustino, M.A.F.; Neves, M.G.P.M.S.; Tomé, A.C.; Cavaleiro, J.A.S.; Cunha, Â. Porphyrin derivatives as photosensitizers for the inactivation of Bacillus cereus endospores. J. Appl. Microbiol. 2009, 106, 1986-1995. [CrossRef]

145. Alves, E.; Carvalho, C.M.; Tomé, J.P.; Faustino, M.A.; Neves, M.G.; Tomé, A.C.; Cavaleiro, J.A.; Cunha, Â.; Mendo, S.; Almeida, A. Photodynamic inactivation of recombinant bioluminescent Escherichia coli by cationic porphyrins under artificial and solar irradiation. J. Ind. Microbiol. Biotechnol. 2008, 35, 1447-1454. [CrossRef]

146. Almeida, J.; Tomé, J.P.; Neves, M.G.; Tomé, A.C.; Cavaleiro, J.A.; Cunha, Â.; Costa, L.; Faustino, M.A.; Almeida, A. Photodynamic inactivation of multidrug-resistant bacteria in hospital wastewaters: Influence of residual antibiotics. Photochem. Photobiol. Sci. 2014, 13, 626-633. [CrossRef]

147. Carvalho, C.M.; Alves, E.; Costa, L.; Tomé, J.P.; Faustino, M.A.; Neves, M.G.; Tomé, A.C.; Cavaleiro, J.A.; Almeida, A.; Cunha, A.; et al. Functional cationic nanomagnet-porphyrin hybrids for the photoinactivation of microorganisms. ACS Nano 2010, 4, 7133-7140. [CrossRef]

148. Alves, E.; Rodrigues, J.M.; Faustino, M.A.; Neves, M.G.; Cavaleiro, J.A.; Lin, Z.; Cunha, Â.; Nadais, M.H.; Tomé, J.P.; Almeida, A. A new insight on nanomagneteporphyrin hybrids for photodynamic inactivation of microorganisms. Dyes Pigment. 2014, 110, 80-88. [CrossRef]

149. McCormick, B.P.P.; Pansa, M.F.; Sanabria, L.N.M.; Carvalho, C.M.; Faustino, M.A.F.; Neves, M.G.P.; Cavaleiro, J.A.; Vittar, N.B.R.; Rivarola, V.A. Cationic porphyrin derivatives for application in photodynamic therapy of cancer. Laser Phys. 2014, 24, 045603. [CrossRef]

150. Chen, J.J.; Gao, L.J.; Liu, T.J. Photodynamic therapy with a novel porphyrin-based photosensitizer against human gastric cancer. Oncol. Lett. 2016, 11, 775-781. [CrossRef] [PubMed]

151. Broughton, L.J.; Giuntini, F.; Savoie, H.; Bryden, F.; Boyle, R.W.; Maraveyas, A.; Madden, L.A. Duramycin-porphyrin conjugates for targeting of tumour cells using photodynamic therapy. J. Photochem. Photobiol. B 2016, 163, 374-384. [CrossRef] [PubMed]

152. Neri, C.R.; Prado, A.P.J.M.; Ribeiro, A.O.; Serra, O.V.A.; Iamamoto, Y. Determination of the photodynamic activity of porphyrins: Potential photosensitizers for treatment of age-related macular degeneration. Mater. Sci. 2002, 20, 69-75.

153. Das, R.A.; Romano, A.; Chiosi, F.; Menzione, M.; Rinaldi, M. Combined treatment modalities for age related macular degeneration. Curr. Drug Targets 2011, 12, 182-189. [CrossRef] [PubMed] 
154. Higashino, T.; Imahori, H. Porphyrins as excellent dyes for dye-sensitized solar cells: Recent developments and insights. Dalton Trans. 2015, 44, 448-463. [CrossRef] [PubMed]

155. Krishna, J.V.; Mrinalini, M.; Prasanthkumar, S.; Giribabu, L. Recent Advances on Porphyrin Dyes for Dye-Sensitized Solar Cells. In Dye-Sensitized Solar Cells; Academic Press: New York, NY, USA, 2019; pp. 231-284. [CrossRef]

156. Sun, D.; Tham, F.S.; Reed, C.A.; Chaker, L.; Burgess, M.; Boyd, P.D. Porphyrin- fullerene host- guest chemistry. J. Am. Chem. Soc. 2000, 122, 10704-10705. [CrossRef]

157. Vinodh, M.; Alipour, F.H.; Mohamod, A.A.; Al-Azemi, T.F. Molecular assemblies of porphyrins and macrocyclic receptors: Recent developments in their synthesis and applications. Molecules 2012, 17, 11763-11799. [CrossRef]

158. Ali, M.F.; Perzanowski, H.; Bukhari, A.; Al-Haji, A.A. Nickel and vanadyl porphyrins in Saudi Arabian crude oils. Energy Fuels 1993, 7, 179-184. [CrossRef]

159. Sundararaman, P.; Raedeke, L.D. Vanadyl porphyrins in exploration: Maturity indicators for source rocks and oils. Appl. Geochem. 1993, 8, 245-254. [CrossRef]

160. Reddy, V.N.; Rekha Rani, K.; Chandana, G.; Sehrawat, S. Photodynamic therapy. Indian J. Dent. Adv. 2009, 1, 46-50.

161. Huang, Z.; Xu, H.; Meyers, A.D.; Musani, A.I.; Wang, L.; Tagg, R.; Barqawi, A.B.; Chen, Y.K. Photodynamic therapy for treatment of solid tumors-potential and technical challenges. Technol. Cancer Res. Treat. 2008, 7, 309-320. [CrossRef] [PubMed]

162. Fowley, C.; Nomikou, N.; McHale, A.P.; McCaughan, B.; Callan, J.F. Extending the tissue penetration capability of conventional photosensitisers: A carbon quantum dot-protoporphyrin IX conjugate for use in two-photon excited photodynamic therapy. Chem. Commun. 2013, 49, 8934-8936. [CrossRef] [PubMed]

163. Josefsen, L.B.; Boyle, R.W. Photodynamic therapy: Novel third-generation photosensitizers one step closer? Br. J. Pharmacol. 2008, 154, 1-3. [CrossRef] [PubMed]

164. Wang, D.; Fei, B.; Halig, L.V.; Qin, X.; Hu, Z.; Xu, H.; Wang, Y.A.; Chen, Z.; Kim, S.; Shin, D.M.; et al. Targeted Iron-Oxide Nanoparticle for Photodynamic Therapy and Imaging of Head and Neck Cancer. ACS Nano 2014, 8, 6620-6632. [CrossRef] [PubMed]

165. Mathews, M.S.; Angell-Petersen, E.; Sanchez, R.; Sun, C.H.; Vo, V.; Hirschberg, H.; Madsen, S.J. The effects of ultra-low fluence rate single and repetitive photodynamic therapy on glioma spheroids. Lasers Surg. Med. 2009, 41, 578-584. [CrossRef] [PubMed]

166. Craig, R.A.; McCoy, C.P.; Gorman, S.P.; Jones, D.S. Photosensitisers-The progression from photodynamic therapy to anti-infective surfaces. Expert Opin. Drug Deliv. 2015, 12, 85-101. [CrossRef] [PubMed]

167. Agostinis, P.; Berg, K.; Cengel, K.A.; Foster, T.H.; Girotti, A.W.; Gollnick, S.O.; Hahn, S.M.; Hamblin, M.R.; Juzeniene, A.; Kessel, D.; et al. Photodynamic therapy of cancer: An update. CA Cancer J. Clin. 2011, 61, 250-281. [CrossRef] [PubMed]

168. Moghissi, K. PDT: The plight. Photodiagn. Photodyn. Ther. 2007, 4, 223-277. [CrossRef]

(C) 2019 by the authors. Licensee MDPI, Basel, Switzerland. This article is an open access article distributed under the terms and conditions of the Creative Commons Attribution (CC BY) license (http://creativecommons.org/licenses/by/4.0/). 